\title{
Global modelling of direct and indirect effects of sea spray aerosol using a source function encapsulating wave state
}

\author{
A.-I. Partanen ${ }^{1}$, E. M. Dunne ${ }^{1}$, T. Bergman ${ }^{1}$, A. Laakso ${ }^{1}$, H. Kokkola ${ }^{1}$, J. Ovadnevaite ${ }^{2}$, L. Sogacheva ${ }^{3}$, D. Baisnée ${ }^{4}$, \\ J. Sciare ${ }^{4}$, A. Manders ${ }^{5}$, C. O'Dowd ${ }^{2}$, G. de Leeuw ${ }^{3,6}$, and H. Korhonen ${ }^{1}$ \\ ${ }^{1}$ Atmospheric Research Centre of Eastern Finland, Finnish Meteorological Institute, Kuopio, Finland \\ ${ }^{2}$ School of Physics and Centre for Climate and Air Pollution Studies, Ryan Institute, National University of Ireland Galway, \\ University Road, Galway, Ireland \\ ${ }^{3}$ Climate change, Finnish Meteorological Institute, Helsinki, Finland \\ ${ }^{4}$ LSCE, CEA-CNRS-UVSQ, Laboratoire des Sciences du Climat et de l'Environnement, Gif-sur-Yvette, France \\ ${ }^{5}$ TNO, Utrecht, the Netherlands \\ ${ }^{6}$ Department of Physics, University of Helsinki, Helsinki, Finland
}

Correspondence to: A.-I. Partanen (antti-ilari.partanen@fmi.fi)

Received: 23 December 2013 - Published in Atmos. Chem. Phys. Discuss.: 20 February

Revised: 27 September 2014 - Accepted: 3 October 2014 - Published: 7 November 2014

\begin{abstract}
Recently developed parameterizations for the sea spray aerosol source flux, encapsulating wave state, and its organic fraction were incorporated into the aerosol-climate model ECHAM-HAMMOZ to investigate the direct and indirect radiative effects of sea spray aerosol particles. Our simulated global sea salt emission of $805 \mathrm{Tg} \mathrm{gr}^{-1}$ (uncertainty range $378-1233 \mathrm{Tg} \mathrm{yr}^{-1}$ ) was much lower than typically found in previous studies. Modelled sea salt and sodium ion concentrations agreed relatively well with measurements in the smaller size ranges at Mace Head (annual normalized mean model bias $-13 \%$ for particles with vacuum aerodynamic diameter $\left.D_{\text {va }}<1 \mu \mathrm{m}\right)$, Point Reyes $(-29 \%$ for particles with aerodynamic diameter $\left.D_{\mathrm{a}}<2.5 \mu \mathrm{m}\right)$ and Amsterdam Island $\left(-52 \%\right.$ for particles with $\left.D_{\mathrm{a}}<1 \mu \mathrm{m}\right)$ but the larger sizes were overestimated $(899 \%$ for particles with $\left.2.5 \mu \mathrm{m}<D_{\mathrm{a}}<10 \mu \mathrm{m}\right)$ at Amsterdam Island. This suggests that at least the high end of the previous estimates of sea spray mass emissions is unrealistic. On the other hand, the model clearly underestimated the observed concentrations of organic or total carbonaceous aerosol at Mace Head $(-82 \%)$ and Amsterdam Island $(-68 \%)$. The large overestimation $(212 \%)$ of organic matter at Point Reyes was due to the contribution of continental sources. At the remote Amsterdam Island site, the organic concentration was underestimated especially in the biologically active months, suggesting a need to improve the parameterization of the organic sea spray frac-
\end{abstract}

tion. Globally, the satellite-retrieved AOD over the oceans, using PARASOL data, was underestimated by the model (means over ocean 0.16 and 0.10 , respectively); however, in the pristine region around Amsterdam Island the measured AOD fell well within the simulated uncertainty range. The simulated sea spray aerosol contribution to the indirect radiative effect was positive $\left(0.3 \mathrm{~W} \mathrm{~m}^{-2}\right)$, in contrast to previous studies. This positive effect was ascribed to the tendency of sea salt aerosol to suppress both the in-cloud supersaturation and the formation of cloud condensation nuclei from sulfate. These effects can be accounted for only in models with sufficiently detailed aerosol microphysics and physics-based parameterizations of cloud activation. However, due to a strong negative direct effect, the simulated effective radiative forcing (total radiative) effect was $-0.2 \mathrm{~W} \mathrm{~m}^{-2}$. The simulated radiative effects of the primary marine organic emissions were small, with a direct effect of $0.03 \mathrm{~W} \mathrm{~m}^{-2}$ and an indirect effect of $-0.07 \mathrm{~W} \mathrm{~m}^{-2}$.

\section{Introduction}

The magnitude of the aerosol radiative effect remains a large unknown in current estimates of anthropogenic effects on radiative forcing (Forster et al., 2007). One of the key quantities needed for better estimates of anthropogenic radiative 
forcing is an accurate estimate of the radiative effects from natural aerosol (Carslaw et al., 2013). It is, after all, the change from the natural background that is important when quantifying human effects on the climate. With over $71 \%$ of the Earth's surface covered by oceans, sea spray aerosol makes a significant contribution to the Earth's radiation balance (Haywood et al., 1999; Rap et al., 2013). Because of their high global emissions and relatively large sizes, sea spray aerosol particles provide a major contribution to the scattering of solar radiation (see de Leeuw et al., 2011), and to a lesser extent of thermal radiation (Li et al., 2008). Furthermore, their size and hygroscopicity make them efficient cloud condensation nuclei $(\mathrm{CCN})$ and they can therefore affect the Earth's climate by modifying marine cloud properties and lifetime (Pierce and Adams, 2006; Korhonen et al., 2008).

The current estimates of global sea spray aerosol emissions remain highly uncertain (de Leeuw et al., 2011), and values ranging over several orders of magnitude have been presented based on recent modelling studies (Textor et al., 2006; Gantt et al., 2012; Grythe et al., 2014). Much of this variation is due to uncertainties in the wind speed dependence of the production flux, or the upper cut-off size of the sea spray aerosol particles included in the models, but also to different experimental methods used to determine the emission parameterizations (de Leeuw et al., 2011). In addition to the amount of sea spray aerosol mass emitted, the chemical composition of sea spray aerosol particles as a function of particle size, location and time remains poorly quantified (Albert et al., 2012; Gantt and Meskhidze, 2013). While inorganic components constitute most of the global sea spray aerosol mass, during biologically active months organic compounds contribute significantly to, and can in some cases even dominate, the mass of submicron sea spray aerosol particles (Novakov et al., 1997; O'Dowd et al., 2004; Facchini et al., 2008; Sciare et al., 2009; Fuentes et al., 2010a, b; King et al., 2012). Recent measurements have indicated that the organic fraction consists of a myriad of chemically distinct types of surface-active compounds (Hawkins and Russell, 2010; Schmitt-Kopplin et al., 2012), but the exact identity of these compounds is largely unknown. Uncertainties also remain regarding the mixing state of the organic matter with sea salt (Middlebrook et al., 1998; Leck and Bigg, 2005; Hultin et al., 2010). Furthermore, Ovadnevaite et al. (2011) noticed that sea spray particles enriched in organic matter show a dichotomous behaviour in terms of water uptake, in that they have a low hygroscopicity in subsaturated conditions but act as very efficient $\mathrm{CCN}$ in supersaturated conditions. All these unknowns and poorly constrained phenomena lead to the current large uncertainty in our estimates of sea spray aerosol radiative effects (Gantt and Meskhidze, 2013).

Recently, Ovadnevaite et al. (2014) developed a new sea spray aerosol source function by combining measurements of aerosol number concentration at the Mace Head station
(O'Connor et al., 2008) and open-ocean eddy correlation fluxes during the SEASAW cruise (Norris et al., 2012). Instead of the commonly used $10 \mathrm{~m}$ wind speed, this source function parameterizes the particle production as a function of the Reynolds number and thus encapsulates the influences of wave height and history as well as sea water viscosity (dependent on the sea surface temperature and salinity). While the new source function predicts sea spray aerosol fluxes on the lower end of other recently published source functions, it was shown to agree well with independent measurements of the submicron sea salt mass measured at Mace Head (Ovadnevaite et al., 2014).

This study provides a further evaluation of the Ovadnevaite et al. (2014) sea spray aerosol source function against a variety of in situ and remote sensing measurements. We have implemented the source function into the global aerosol-climate model ECHAM-HAMMOZ, and extended the parameterization to include organic enrichment of sea spray aerosol particles based on recent work by Rinaldi et al. (2013). After the evaluation, we use the source function together with ECHAM-HAMMOZ to provide estimates of the direct and indirect radiative effects of sea spray aerosol and the impact of organic enrichment of sea spray aerosol particles to radiative effects.

\section{Methods}

\subsection{Climate model ECHAM-HAMMOZ}

The global aerosol-climate model ECHAM-HAMMOZ (ECHAM5.5-HAM-SALSA) (Stier et al., 2005; Zhang et al., 2012; Bergman et al., 2012) consists of an atmospheric core model ECHAM, which solves the fundamental equations for atmospheric flow and physics, and tracer transport, and of an aerosol model HAM. In this study, aerosol microphysics was calculated using the sectional model SALSA (Kokkola et al., 2008; Bergman et al., 2012). SALSA describes the aerosol population consisting of sulfate, sea salt, organic matter, black carbon and dust using 10 size sections to cover the size range from $3 \mathrm{~nm}$ to $10 \mu \mathrm{m}$, with 10 additional sections to account for the external mixing of particles. The model resolves the aerosol processes of nucleation of new particles (Kulmala et al., 2006), condensation of sulfuric acid and organic gases onto pre-existing particles, coagulation, hydration, and removal of particles via dry and wet deposition.

The anthropogenic and biomass burning aerosol emissions in the model were taken from AeroCom-II ACCMIP data (Riahi et al., 2007, 2011). Natural emissions were simulated as described in Zhang et al. (2012), apart from the sea salt and primary marine organic matter (PMOM) emissions which are detailed in Sect. 2.2. Interactions between aerosols and radiation were calculated online (Zhang et al., 2012), and the total aerosol direct effect was diagnosed by a second call of the radiation routine without any aerosols. The first and 
second indirect effects were calculated following Lohmann and Hoose (2009). The activation of aerosol particles into cloud droplets was calculated with the physically based parameterization of Abdul-Razzak and Ghan (2002).

\subsection{Implementation of the sea spray aerosol source function}

The standard version of ECHAM-HAMMOZ simulates the sea salt source flux by combining the parameterizations of Gong (2003) with dry diameter between 50 and $400 \mathrm{~nm}$, of Monahan et al. (1986) for particles with dry diameter between $400 \mathrm{~nm}$ and $8 \mu \mathrm{m}$, and of Andreas (1998) for particles with dry diameters of 8-10 $\mu \mathrm{m}$ (Guelle et al., 2001; Bergman et al., 2012). Furthermore, it does not include emissions of PMOM. For the current study, we implemented the recently developed source function by Ovadnevaite et al. (2014) into the model, and combined it with the approach of Rinaldi et al. (2013) to account for the fraction of PMOM as a function of chlorophyll $a$ concentration and $10 \mathrm{~m}$ wind speed.

The Ovadnevaite et al. (2014) parameterization describes the sea spray aerosol flux in the size range $15 \mathrm{~nm}-6 \mu \mathrm{m}$ in diameter, whereas the aerosol module SALSA used in this study tracks sea spray aerosol particles between $30 \mathrm{~nm}$ and $10 \mu \mathrm{m}$. Correspondingly, we used the Ovadnevaite et al. (2014) parameterization for the particle diameter range $30 \mathrm{~nm}-6 \mu \mathrm{m}$, and extended it over the size range $6-10 \mu \mathrm{m}$ by using (the shape of) the Monahan (1986) source function, but matching the flux at $6 \mu \mathrm{m}$ with the Ovadnevaite et al. (2014) flux. Using this approach, the simulated sea spray aerosol flux for particles larger than $6 \mu \mathrm{m}$ was significantly lower than in the original Monahan (1986) formulation. Hereafter, we refer to the original parameterization by Ovadnevaite et al. (2014) as the OSSA source function, and to the combined flux parameterization of Ovadnevaite et al. (2014) and scaled Monahan (1986) as the extended OSSA source function.

The Ovadnevaite et al. (2014) sea spray aerosol source function has been parameterized in terms of five lognormal modes (Table 1):

$$
\frac{\mathrm{d} F}{\operatorname{dog}_{10} D}=\sum_{i=1}^{5} \frac{F_{i}\left(R_{\mathrm{Hw}}\right)}{\sqrt{2 \pi} \log _{10} \sigma_{i}} \exp \left(-\frac{1}{2}\left(\frac{\log _{10}\left(\frac{D}{D_{\mathrm{g}, i}}\right)}{\log _{10}\left(\sigma_{i}\right)}\right)^{2}\right),
$$

where $D$ is particle dry diameter, $\sigma_{i}$ and $D_{\mathrm{g}, i}$ are geometric standard deviation and geometric mean (count-median) dry diameter of mode $i$, respectively, and $F_{i}\left(R_{\mathrm{Hw}}\right)$ is total number flux of mode $i$ depending on the Reynolds number:

$R_{\mathrm{Hw}}=u_{*} H_{\mathrm{s}} / \nu_{\mathrm{w}}$.

Here $u_{*}$ is the friction velocity calculated online by the ECHAM-HAMMOZ model, $H_{\mathrm{s}}$ is the significant height of wind-generated waves (four times the standard deviation of sea surface elevation or roughly the average height of the
Table 1. Log-normal parameters for the Ovadnevaite et al. (2014) sea spray source function. The geometric standard deviation for each mode is denoted by $\sigma_{i}$, the geometric mean (count-median) diameter by $D_{\mathrm{g}, i}$, and the mode total number flux by $F_{i}\left(R_{\mathrm{Hw}}\right)$. The number flux is expressed as a function of Reynolds number $\left(R_{\mathrm{Hw}}\right)$.

\begin{tabular}{cccl}
\hline$i$ & $\sigma_{i}$ & $D_{\mathrm{g}, i}$ & $F_{i}\left(R_{\mathrm{Hw}}\right)$ \\
\hline 1 & 1.37 & 0.018 & $104.51 \cdot\left(R_{\mathrm{Hw}}-10^{5}\right)^{0.556}$ \\
2 & 1.50 & 0.041 & $0.044 \cdot\left(R_{\mathrm{Hw}}-10^{5}\right)^{1.08}$ \\
3 & 1.42 & 0.090 & $149.64 \cdot\left(R_{\mathrm{Hw}}-10^{5}\right)^{0.545}$ \\
4 & 1.53 & 0.233 & $2.96 \cdot\left(R_{\mathrm{Hw}}-10^{5}\right)^{0.79}$ \\
5 & 1.85 & 0.830 & $0.52 \cdot\left(R_{\mathrm{Hw}}-2 \times 10^{5}\right)^{0.87}$ \\
\hline
\end{tabular}

Table 2. Kinematic viscosity $\left(v_{\mathrm{w}}\right)$ of sea water at different sea water temperatures $\left(T_{\mathrm{W}}\right)$. Data were interpolated for water salinity of $35 \mathrm{~g} \mathrm{~kg}^{-1}$ with parameterization by Sharqawy et al. (2010).

\begin{tabular}{cc}
\hline$T_{\mathrm{W}}\left({ }^{\circ} \mathrm{C}\right)$ & $\mathcal{v}_{\mathrm{W}}\left(10^{-6} \mathrm{~m}^{2} \mathrm{~s}^{-1}\right)$ \\
\hline 0 & 1.854 \\
10 & 1.360 \\
20 & 1.051 \\
30 & 0.843 \\
40 & 0.695 \\
\hline
\end{tabular}

highest one-third of the waves) taken from 6 hourly ECMWF reanalysis data (see Sect. 2.3), and $v_{\mathrm{w}}$ is the temperaturedependent kinematic viscosity of sea water. We calculated the viscosity by linear interpolation from the values in $\mathrm{Ta}$ ble 2 and by assuming that the salinity of sea water is $35 \mathrm{~g} \mathrm{~kg}^{-1}$ (see Ovadnevaite et al., 2014, for a discussion on the effect of salinity). This implicit temperature dependence of the OSSA source function is similar to the results of Jaeglé et al. (2011) (Ovadnevaite et al., 2014).

Number and volume fluxes of sea spray aerosol particles for each of the SALSA size sections below $6 \mu \mathrm{m}$ were calculated by integrating over each of the five modal OSSA emissions distributions separately. For particles smaller than $700 \mathrm{~nm}$ in diameter, SALSA tracks both number and mass separately. In the size range $30-700 \mathrm{~nm}$, both the number and volume distributions were integrated for each section. In the size range above $700 \mathrm{~nm}$, the size sections in SALSA have a fixed dry diameter and only the aerosol number is tracked in each section. It was therefore not possible to set both number and volume emissions equal to the exact integral of the OSSA distributions for that size range. We chose to calculate the volume emissions exactly and, using the fixed section sizes, converted the emitted volume flux to a corresponding number emission flux.

Due to the nature of its derivation, using data obtained in the winter with low biological activity, the OSSA source function represents the total emission of sea spray aerosol particles. In this work, due to lack of further information, it was assumed that the total emission flux does not change 
during periods of higher biological activity - that is, the function describes the total flux, including both sea salt and PMOM. For sea spray aerosol particles larger than $700 \mathrm{~nm}$ in diameter, SALSA does not explicitly track the organic fraction, i.e. all sea spray aerosol particles are assumed to consist solely of sea salt. This introduces a relatively small error since these large particles contain only a small fraction of organic matter (Facchini et al., 2008). For smaller particles, the mass fraction of the PMOM in the sea spray aerosol emissions ( $f_{\mathrm{PMOM}}$ ) was calculated following Rinaldi et al. (2013):

$$
f_{\mathrm{PMOM}}=\left(0.569 \times c_{\mathrm{Chl} a}\right)+\left(-0.0464 \times u_{10 \mathrm{~m}}+0.409\right),
$$

where $c_{\mathrm{Chl} a}$ is the chlorophyll $a$ concentration in surface water $\left(\mu \mathrm{g} \mathrm{m}^{-3}\right)$ and $u_{10 \mathrm{~m}}$ is the $10 \mathrm{~m}$ wind speed $\left(\mathrm{m} \mathrm{s}^{-1}\right)$. The chlorophyll $a$ concentration in the current study was taken from GlobColour satellite retrievals, as it was in $\mathrm{Ri}$ naldi et al. (2013). We used the mean value of the previous 8-day period to account for the lag in correlation between organic mass fraction and chlorophyll $a$ concentration (Rinaldi et al., 2013) (see Sect. 2.3 for details).

We acknowledge that the production of PMOM is poorly understood (e.g. Quinn et al., 2014; Long et al., 2014) and the ability of any currently available parameterization to predict the organic fraction of sea spray is limited. The Rinaldi et al. (2013) parameterization used in this study for the organic fraction of sea spray is derived from long-term data in the North Atlantic, which show that chlorophyll $a$ concentration with an 8-day time lag is a useful proxy of organic enrichment in this region. The usefulness of chlorophyll $a$ proxy for medium timescales on larger areas was also shown by Gantt et al. (2012). However, the parameterization has not yet been evaluated in other regions against long-term data. Recent studies have reported localized or short-term events for which correlation between the chlorophyll $a$ concentration and organic enrichment has not been observed (Bates et al., 2012; Long et al., 2014; Quinn et al., 2014); however, these measurements do not fulfil the 8-day time lag criterion of the Rinaldi et al. (2013) parameterization as they correlate instantaneous chlorophyll $a$ concentrations with the organic enrichment. Moreover, parameterizations taking these recent findings into account do not yet exist. The complex relationship between oceanic biological activity and organic enrichment calls for more long-term data sets from different regions of the world's oceans to improve the parameterizations.

To distinguish PMOM from organics from other sources, the aerosol model was extended to include a new tracer for PMOM in each of the four size sections in the range $30-700 \mathrm{~nm}$. The same organic mass fraction was used for emissions in all four size sections (i.e., no size dependency was assumed). The density of the PMOM was assumed to be $1300 \mathrm{~kg} \mathrm{~m}^{-3}$, its molar mass was set to $150 \mathrm{~g} \mathrm{~mol}^{-1}$, and its refractive index was set to $1.48+10^{-9} i$ at all wavelengths $(0.28-4 \mu \mathrm{m})$ to reflect recent measurements (Aas,
1996; Kanakidou et al., 2005; Nessler et al., 2005; Vaishya et al., 2013).

As mentioned earlier, Ovadnevaite et al. (2011) observed that PMOM at Mace Head shows a dichotomous behaviour: a low hygroscopicity at subsaturated conditions but a high $\mathrm{CCN}$ activity at supersaturated conditions. This was accounted for in the model in the following way: the liquid water content (LWC) resulting from water uptake by sea salt and PMOM was calculated from

$$
\mathrm{LWC}_{\mathrm{SS}+\mathrm{PMOM}}=\left(V_{\mathrm{SS}}+V_{\mathrm{PMOM}}\right) \times\left(\mathrm{HGF}^{3}-1\right) \times \rho_{\mathrm{W}},
$$

where $V_{\mathrm{SS}}$ and $V_{\mathrm{PMOM}}$ are the volume concentrations of sea salt and marine PMOM and $\rho_{\mathrm{W}}$ is the density of water. The hygroscopic growth factor HGF was obtained by bi-linear interpolation of the values from the look-up table by Vaishya et al. (2013) for the relative humidity and PMOM mass fraction in each model grid box. For example, growth factors at a relative humidity of $90 \%$ for pure PMOM and pure sea salt particles were 1.3 and 2.3 , respectively. The total LWC of the particles was calculated by adding up $\mathrm{LWC}_{\mathrm{SS}+\mathrm{PMOM}}$ and LWC for other aerosol compounds calculated using the ZSR method (Stokes and Robinson, 1996) as described in Kokkola et al. (2008).

Since a theoretical understanding of the high CCN activity of PMOM is currently lacking, we tuned the modelled cloud activation of PMOM to approximately match the observations of Ovadnevaite et al. (2011). In order to do this, we used the cloud-activation subroutine of the model (Abdul-Razzak and Ghan, 2002) in a 0-D framework together with a representative marine aerosol size distribution from the model simulations. We then adjusted the dissociation coefficient of PMOM (i.e. into how many ions each PMOM molecule splits in a solution) within this subroutine so that when the mass fraction of PMOM was $50 \%$, all soluble particles larger than $30 \mathrm{~nm}$ in diameter were activated at a supersaturation of about $0.7 \%$ (see Ovadnevaite et al., 2011). The best match was obtained when the dissociation coefficient was set to five. It is important to note that the chosen value of dissociation coefficient affects only the cloud activation routine of the model and is not physically based. Its purpose is only to fit the model results to match observations of Ovadnevaite et al. (2011).

With the given densities, molar masses and dissociation constants, the $\mathrm{CCN}$-derived $\kappa$ values (Petters and Kreidenweis, 2007) for PMOM and sea salt (assumed to be sodium chloride in the model) were 0.78 and 1.33 , respectively. The difference means that although PMOM has a very high activation efficiency compared to e.g. other organic matter in the model $(\kappa=0.24)$, its activation efficiency is lower than that of sea salt in the model. The activation efficiency of sea salt in the model is, on the other hand, higher than in ambient measurements due to the assumption that sea salt consists of pure sodium chloride. In supersaturated conditions, $\kappa$ of PMOM is also greater than the average marine $\kappa$ of 0.63 at the boundary layer height modelled by Pringle et al. (2010). 
This means that the presence of PMOM, on average, probably increases the activation efficiency of marine aerosol when all other components are held constant. However, as PMOM in our model setup replaces part of the sea salt in the source function, it decreases the cloud activation efficiency of sea spray. Using the $\mathrm{CCN}$-derived $\kappa$ of PMOM gives a growth factor of 2 at a relative humidity of $90 \%$ (Petters and Kreidenweis, 2007). This value is larger than any growth factor measured by Ovadnevaite et al. (2011), which means that our model setup is consistent with their measurements, although the cloud activation efficiency of PMOM is lower than that of pure sea salt in the model.

\subsection{Input data for the sea spray aerosol source function}

ECHAM-HAMMOZ is an atmosphere-only model and therefore does not predict the significant height of windgenerated ocean waves. However, this quantity was needed to calculate the Reynolds number (Eq. 2) in the OSSA source function. We obtained the significant wave height from the Global Wave Analysis Data Set by the European Centre for Medium-range Weather Forecasts (ECMWF) at a $6 \mathrm{~h}$ time resolution over the whole simulated time period (Uppala et al., 2005). Since all model simulations presented in this study were nudged to the ECMWF winds, the off-line wave height data are expected to correspond well to the simulated surface wind fields.

The $1^{\circ} \times 1^{\circ}$ wave height data from the Global Wave Analysis Data Set was interpolated to the ECHAM-HAMMOZ model resolution of T63. Since the land-sea masks of the wave height data and the ECHAM-HAMMOZ model were not identical, we needed to fill in some blank values over the model ocean grid cells after the interpolation. This was done by using the average values of the neighbouring grid cells in the blank grid cells.

The chlorophyll $a$ data needed to calculate the PMOM mass fraction of sea spray aerosol emissions (Eq. 3) were obtained from satellite retrievals (http://www.globcolour.info). GlobColour provides two chlorophyll retrievals, CHL1 and CHL2. The retrieval of the CHL1 data set makes use of the assumption that variations in ocean colour in open water are caused by phytoplankton or co-varying substances. Near the coast, other dissolved substances can cause significant changes in ocean colour, and the retrieval algorithms used to provide the CHL2 data set try to take this into account.

We used 8-day-mean $1^{\circ} \times 1^{\circ}$ GlobColour retrievals of CHL1 and CHL2 data for the years 2005-2010. The data sets were combined by using the CHL2 data within four grid boxes of the coast and the CHL1 data elsewhere (Garver-Siegel-Maritorena (GSM) model; Maritorena and Siegel, 2005). Due to cloud cover and breaks in satellite observations, there were still large gaps present in the data set. These gaps were filled using the Multiple Singular-Spectrum Analysis (MSSA) toolkit Spectra (Kondrashov and Ghil,
2006). MSSA works by fitting periodic functions to the data. The maximum period of any of these functions is known as the window length (in our case, 46 8-day-mean data points, or 1 year's worth of data). MSSA includes information from both spatial and temporal neighbours when fitting a periodic function to fill the gaps.

A large portion of the winter hemisphere is outside the satellite field of view. This systematic omission of wintertime data is a major challenge in providing a chlorophyll data set suitable for use in a global climate model, as the fitting algorithms will not capture the low winter-time chlorophyll values when only provided with high summer-time data. To remedy this, we first read in the maximum and minimum observed latitude from each 8-day-mean satellite retrieval file. Outside of this latitude range, the chlorophyll concentration in a given grid cell $\left(C_{i}\right)$ was then set according to the following approximate formula:

$C_{i}=C_{\mathrm{b}} \times\left(\frac{1}{2}\right)^{\left|\frac{\mathrm{lat}_{i}-\mathrm{lat}_{\mathrm{b}}}{4}\right|}$,

where $C_{\mathrm{b}}$ is the value in the nearest marine grid cell to the latitude boundary, lat ${ }_{i}$ is the latitude (in degrees) of grid cell $i$, and lat $t_{\mathrm{b}}$ is the latitude of the boundary value (either highest or lowest latitude with a value for chlorophyll concentration). Due to the extreme seasonal variations in chlorophyll at high latitudes, this method may still lead to some underestimation in the summer hemisphere, where polar chlorophyll values can be extremely high, and some overestimation in the winter hemisphere where chlorophyll would be close to zero (see Albert et al., 2012, for a discussion of the effect of gap-filling methods). However, it is still expected to provide more accurate values than simply filling in winter-time values based on summer observations.

After the temporal gap-filling was done for the chlorophyll $a$ data, the remaining gaps, due to either totally missing data in some grid cells or differences in land-sea masks between the data and our model, were filled with the same procedure as described above for the wave height data.

\subsection{Observational data for model evaluation}

\subsubsection{In situ measurements to evaluate aerosol chemical composition}

Continuous marine aerosol physico-chemical measurements are undertaken at the Mace Head atmospheric research station $\left(54^{\circ} 19^{\prime} \mathrm{N}, 9^{\circ} 54^{\prime} \mathrm{W}\right.$, see Fig. 1), located on the west coast of Ireland (O'Connor et al., 2008). Aerosol measurements are performed by sampling ambient particles at $10 \mathrm{~m}$ above ground level through a community air-sampling duct. The size-resolved non-refractory chemical composition of submicron aerosol particles is measured with an Aerodyne High Resolution Time of Flight Aerosol Mass Spectrometer (HR-ToF-AMS) deployed in standard mode (DeCarlo et al., 2006). HR-ToF-AMS particulate matter with 


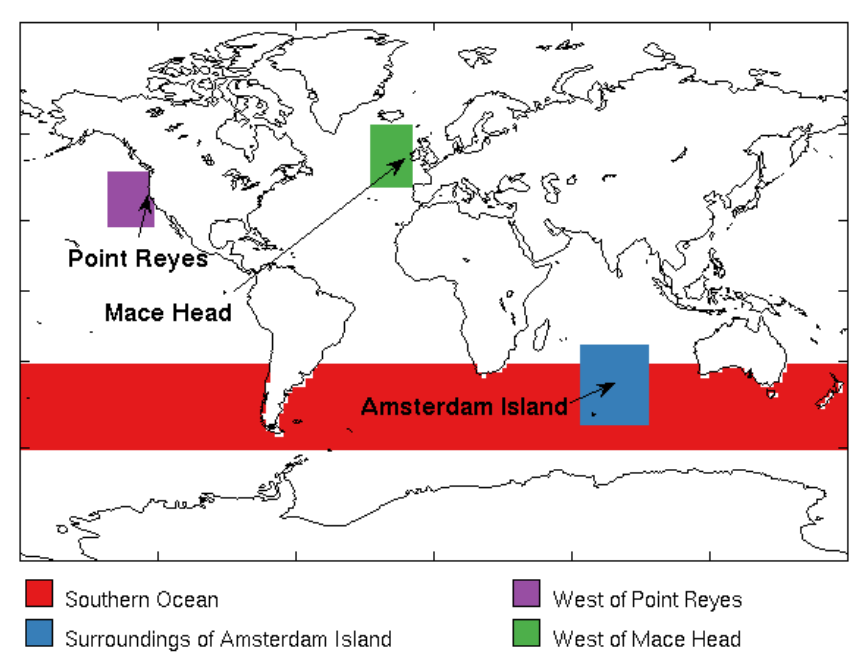

Figure 1. The locations of the three in situ measurement stations, and ocean masks used for aerosol optical depth calculations.

(vacuum aerodynamic) diameter below $1 \mu \mathrm{m}\left(\mathrm{PM}_{1}\right)$ sea salt concentrations were derived following the method described in Ovadnevaite et al.( 2012). The HR-ToF-AMS was routinely calibrated according to the methods described by Jimenez et al. (2003) and Allan et al. (2003). The measurements were performed with a time resolution of $5 \mathrm{~min}$ and a vaporizer temperature of $\sim 650^{\circ} \mathrm{C}$. Compositiondependent collection efficiency was applied for the measurements used here, and ranged from 0.45 to 0.97 . Aerosol size distributions and number concentrations were measured using a scanning mobility particle sizer (SMPS) system. The system comprised of a differential mobility analyser (DMA, TSI model 3071), a condensation particle counter (TSI model 3010), and an aerosol neutralizer (TSI 3077). The aerosol diameter range covered was 3-500 nm. Before their sizes were measured, the particles were dried to a relative humidity below $40 \%$. For this study we used the Mace Head measurement data covering both marine and continental air masses to make the results comparable with modelled mean conditions.

Continuous physico-chemical measurements of marine aerosol are undertaken also at the Amsterdam Island atmospheric research station $\left(37^{\circ} 48^{\prime} \mathrm{S}, 77^{\circ} 34^{\prime} \mathrm{E}\right.$, see Fig. 1), located in the southern Indian Ocean sector of the Austral Ocean. The station is located at 3400 and $5000 \mathrm{~km}$ from the nearest upwind lands (Madagascar and South Africa, respectively). Throughout most of the year, it benefits from pristine marine conditions, especially during the summer when high-pressure conditions and low wind speeds are prevailing. Size-segregated aerosols in four size ranges $\left(D_{\mathrm{a}}<1 \mu \mathrm{m} ; 1 \mu \mathrm{m}<D_{\mathrm{a}}<2.5 \mu \mathrm{m} ; 2.5 \mu \mathrm{m}<D_{\mathrm{a}}<\right.$ $10 \mu \mathrm{m} ; D_{\mathrm{a}}>10 \mu \mathrm{m}$, where $\left.D_{\mathrm{a}}=D \cdot(\rho / 1000)^{1 / 2}\right)$ is the aerodynamic diameter) were sampled at about $30 \mathrm{~m}$ a.s.l. every 8 days for the period 2006-2008. Sampling was car- ried out on preweighed Teflon filters for PM (gravimetry) and ion composition analyses, and on pre-fired quartz filters for EC and OC measurements. Aerosol size segregation was achieved using a four-stage cascade impactor (Dekati Ltd) running at $30 \pm 1$ LPM. A detailed description of the site characteristics and the chemical analytical protocols used to determine ion and carbon contents in aerosols is provided by Sciare et al. (2009). Given the remote character of the site, no clean-sector strategy was necessary to avoid local contaminations. However, a post-sampling data treatment was applied to the database, discarding all samples associated with an equivalent black carbon (EBC) value higher than $10 \mathrm{ng} \mathrm{Cm}^{-3}$, which effectively excludes all anthropogenically contaminated samples. To compare the measurements with the modelled total carbonaceous aerosol mass concentrations, the total carbon concentration measurements from Amsterdam Island were multiplied with 1.8 to account for compounds other than carbon.

Chemical aerosol composition data from Point Reyes (Fig. 1) were obtained from the Interagency Monitoring of Protected Visual Environments (IMPROVE) network. PM 2.5 , sulfate, sea salt and organic matter concentrations were used in this study. Ion chromatography methods from the Nylasorb substrate, extracted ultrasonically in de-ionized water, are used by the IMPROVE network to analyse inorganic ions, while organic carbon is analysed from quartz fibre filters. An average ambient particulate organic compound was assumed to have a constant fraction of carbon by weight (56\%), which was used to correct the organic carbon mass for other elements (in addition to carbon) associated with the assumed organic molecular composition. Therefore, organic matter (OM) mass concentration is assumed to be $\mathrm{OM}=1.8 \cdot \mathrm{OC}$ where $\mathrm{OC}$ is organic carbon mass concentration. A detailed IMPROVE monitoring program description is presented by Malm et al. (2004).

Simulated sea spray aerosol mass concentration values in Europe were evaluated also by comparing surface-level model data to measurements of the sodium ion $\left(\mathrm{Na}^{+}\right)$concentration in total $\mathrm{PM}_{2.5}$ and $\mathrm{PM}_{10}$ values from remote stations of the European Monitoring and Evaluation Programme (EMEP, http://www.emep.int, 2013). Model $\mathrm{Na}^{+}$ values were calculated by assuming that sea spray consists only of sodium chloride, and the $\mathrm{Na}^{+} / \mathrm{SS}$ ratio is therefore $22.99 / 58.44$. We have compared monthly mean values from both the model and the observations. In cases where a single model grid box contained more than one station, we averaged the stations' data. Aerodynamic diameter was used for the cut-off diameter of $\mathrm{PM}_{2.5}$ and $\mathrm{PM}_{10}$ in the model.

\subsubsection{Satellite and sun photometer data for aerosol optical depth comparison}

For the evaluation of the modelled aerosol optical depth (AOD), i.e. the column-integrated extinction, two independent data sets were used: AERONET sun photometer data 
and satellite retrieved AOD. AERONET is a global network of sun photometers (Holben et al., 1998) which directly measure the solar radiation as well as scattered (diffuse) radiation over a large number of angles. Together this provides highly accurate information on the aerosol properties at each site. The AOD is measured with an accuracy of 0.015 (Eck et al., 1999). In our study we used monthly mean cloud-screened and quality assured Level 2.0 data from 17 island and 24 coastal AERONET stations which have at least 1 month of data in the period 2006-2010, and which are located below $2000 \mathrm{~m}$ altitude. The $500 \mathrm{~nm}$ AERONET AOD measurements were interpolated to $550 \mathrm{~nm}$ using $\tau_{550}=\tau_{500} \times(550 / 500)^{-\alpha}$, where $\tau_{500}$ and $\tau_{550}$ are the AODs for 500 and $550 \mathrm{~nm}$, respectively. For $\alpha$, we use the monthly mean Ångström exponent for extinction between 440 and $870 \mathrm{~nm}$ (Mielonen et al., 2011).

The second data source used was the AOD retrieved from the POLDER (POLarization and Directionality of the Earth's Reflectances) radiometer onboard the PARASOL (Polarization and Anisotropy of Reflectances for Atmospheric Science coupled with Observations from a Lidar) satellite. Launched in year 2005 as part of the A-train mission (L'Ecuyer and Jiang, 2010), PARASOL has a sun-synchronized orbit with $1.30 \mathrm{p} . \mathrm{m}$. ascending node.

The POLDER instrument measures the polarized light in different directions and at different wavebands; the use of these data in dedicated retrieval algorithms provides the bestpossible information on aerosol (as well as cloud) optical and physical properties (Deschamps et al., 1994). Comparison of the AOD retrieved over ocean using PARASOL data with AERONET ground-based measurements (Holben et al., 1998) has shown a very good correlation (0.91) with a bias of around 0.03 (Bréon et al., 2011). Validation of the PARASOL AOD using different statistical methods has shown that PARASOL provides a very high accuracy over ocean and covers features well (de Leeuw et al., 2013).

Aerosol products retrieved with PARASOL (Tanré et al., 2011) are provided at an $18.5 \mathrm{~km} \times 18.5 \mathrm{~km}$ resolution. For the comparison with model results, PARASOL AOD for the oceans was remapped to the model resolution of T63 and interpolated from a wavelength of 865 to $550 \mathrm{~nm}$ using monthly mean Ångström exponent from PARASOL.

AOD observations from both AERONET and PARASOL are retrieved under clear-sky conditions, whereas the modelled AOD is calculated over all time steps. This difference may cause overestimation of AOD as relative humidity is higher near clouds, which increases water uptake and thus optical depth of hygroscopic aerosols. In addition, there is uncertainty in the model-measurements comparison as aerosol concentrations and cloud fields depend partly on each other for example through precipitation and wet deposition. However, large-scale patterns and long-term averages are affected considerably less by this uncertainty than local transient values.

\subsection{Design of the experiments}

To test the new source function we set up several model simulations, summarized in Table 3. The control simulation (control) had no sea spray aerosol emissions at all. Our baseline run (ossa-ref) simulated the sea spray aerosol flux using the extended OSSA source function, as described in Sect. 2.2. In order to separate the respective radiative effects of sea salt and PMOM, we also made a run using the extended OSSA source function, but excluding PMOM emissions (simulation ossa-salt).

Ovadnevaite et al. (2014) estimated that the uncertainty in the submicron part of their source function is in the range of $55-60 \%$. It is caused by uncertainties in e.g. particle concentration measurements and boundary layer height. Therefore, to test the sensitivity of our results to these uncertainties, we assumed the same uncertainty in the whole size range and set up two sensitivity runs (ossa-lowflux and ossa-highflux) in which the sea spray aerosol flux from the extended OSSA source function was multiplied by 0.4 and 1.6 , respectively.

When comparing the simulated aerosol fields with in situ and remote sensing measurements, discrepancies may arise, not only from uncertainties in the modelled source function, but also from uncertainties in the modelled removal mechanisms. To test the effect of the removal description, we set up two additional sensitivity simulations with decreased (ossalow-ics) and increased (ossa-high-ics) in-cloud scavenging coefficients in stratiform clouds (Table 4) but otherwise identical to the baseline run (ossa-ref). The in-cloud scavenging coefficient gives the fraction of in-cloud aerosol particles inside cloud droplets. In the case of precipitation, they are removed from the atmosphere. The low and high values of in-cloud scavenging coefficients for the size ranges of 30-700 nm and $700 \mathrm{~nm}-10 \mu \mathrm{m}$ were estimated using measurements by Henning et al. (2004). They measured the scavenging coefficients for liquid phase clouds to be about 1 at the diameter of about $400 \mathrm{~nm}$, and hence we used 0.99 for the larger size range also in the simulation ossa-low-ics. Incloud scavenging is a major removal mechanism for marine aerosol (Textor et al., 2006) and the modelled aerosol burdens have been shown to be sensitive to in-cloud scavenging parameterizations in ECHAM-HAMMOZ (Croft et al., 2010).

For comparison, we also ran the ECHAM-HAMMOZ model with its default sea spray aerosol source function (see Sect. 2.2), i.e. using a combination of Gong (2003), Monahan et al. (1986), and Andreas (1998) source functions without any PMOM emissions (simulation default-salt).

All simulations were run with a model resolution T63L31, corresponding to a $1.9^{\circ} \times 1.9^{\circ}$ grid in the horizontal and 31 vertical levels extending to $10 \mathrm{hPa}$. The model meteorology was nudged towards the reference state of the ERA-interim reanalysis data (Dee et al., 2011). Sea surface temperatures were prescribed from the reanalysis data. The model runs covered the years 2006-2010 and were preceded by a 5-year 
Table 3. List of simulations.

\begin{tabular}{ll}
\hline Simulation name & Description \\
\hline control & No sea spray emissions \\
ossa-ref & Baseline extended OSSA source function \\
ossa-salt & Extended OSSA source function without organic component \\
default-salt & Model default source function for sea salt \\
ossa-lowflux & Extended OSSA source function multiplied by 0.4 \\
ossa-highflux & Extended OSSA source function multiplied by 1.6 \\
ossa-low-ics & Decreased in-cloud scavenging coefficients (see Table 4) \\
ossa-high-ics & Increased in-cloud scavenging coefficients (see Table 4) \\
\hline
\end{tabular}

Table 4. In-cloud scavenging coefficients for soluble particles in stratiform clouds used in different runs. Default values are used in all other runs except in ossa-low-ics and ossa-high-ics. Scavenging coefficients for insoluble particles were kept at the model default values in all runs.

\begin{tabular}{lccc}
\hline & Liquid clouds & Mixed clouds & Ice clouds \\
\hline Default & & & \\
\hline $30-700 \mathrm{~nm}$ & 0.85 & 0.75 & 0.1 \\
$700 \mathrm{~nm}-10 \mu \mathrm{m}$ & 0.99 & 0.75 & 0.1 \\
\hline ossa-low-ics & & & \\
\hline 30-700 nm & 0.5 & 0.65 & 0.05 \\
$700 \mathrm{~nm}-10 \mu \mathrm{m}$ & 0.99 & 0.65 & 0.05 \\
\hline ossa-high-ics & & & \\
\hline 30-700 nm & 0.99 & 0.85 & 0.15 \\
$700 \mathrm{~nm}-10 \mu \mathrm{m}$ & 0.99 & 0.85 & 0.15 \\
\hline
\end{tabular}

spin-up to allow the aerosol system to reach equilibrium. The first 4 years and 10 months of the spin-up had no sea spray aerosol emissions. Each simulation then had a final two-months spin-up period using the appropriate sea spray aerosol emissions.

\section{Evaluation of the extended OSSA source function}

\subsection{Emissions and burdens}

Table 5 summarizes the emissions and burdens of sea salt and PMOM in the different simulations. The baseline run ossaref produced a global emission of sea salt of $805 \mathrm{Tg} \mathrm{yr}^{-1}$ in the $\mathrm{PM}_{10}$ size range, with the sensitivity simulations using the extended OSSA source function suggesting a range of $378-1233 \mathrm{Tg} \mathrm{yr}^{-1}$. These values were approximately an order of magnitude lower than the $7229 \mathrm{Tg} \mathrm{yr}^{-1}$ yielded by the default ECHAM-HAMMOZ sea spray aerosol source function in the default-salt simulation, and on the low side of previously reported estimates. The AeroCom phase I models simulated a median global sea salt emission of $6280 \mathrm{Tgyr}^{-1}$ (mean $16600 \mathrm{Tg} \mathrm{yr}^{-1}$ ) (Textor et al., 2006). More recently, Tsigaridis et al. (2013) compared several sea spray aerosol source functions within their global model and obtained a range of global sea salt emissions from 2272 to $12462 \mathrm{Tg} \mathrm{yr}^{-1}$. Grythe et al. (2014) reviewed 21 different sea salt source functions and calculated annual mean emissions in the range of $\sim 1830-2.44 \times 10^{6} \mathrm{Tg} \mathrm{yr}^{-1}$. These data demonstrate the large uncertainties associated with current estimates of sea spray aerosol emissions. (Note that only a fraction of the discrepancy is explained by different model studies using different upper cut-off sizes for the sea salt emissions).

The simulated sea salt burden in the current study was also at the low end of published values, consistent with the low emissions obtained using the OSSA source function (Ovadnevaite et al., 2014). The baseline run ossa-ref gave a burden of $2.9 \mathrm{Tg}$, and the sensitivity simulations a range of $1.2-4.6 \mathrm{Tg}$. Of the sea salt burden, $17 \%$ was in the size range of $\mathrm{PM}_{1}, 42 \%$ in $\mathrm{PM}_{1-2.5}$, and $41 \%$ in $\mathrm{PM}_{2.5-10}$. Again, these values were approximately an order of magnitude lower than those obtained using the default sea spray aerosol flux in ECHAM-HAMMOZ (12.9 Tg in simulation default-salt) and also smaller than the AeroCom phase I median burden of $6.37 \mathrm{Tg}$ (mean $7.52 \mathrm{Tg}$ ) (Textor et al., 2006). It is interesting to note that the uncertainty due to the in-cloud scavenging in stratiform clouds had a negligible effect on the simulated sea salt burden (runs ossa-low-ics and ossa-high-ics). However, this is in line with a sensitivity study by Andersson et al. (2014), where the SALSA aerosol model coupled to the air quality model MATCH was evaluated. In their study, these authors found that the aerosol size distributions were fairly insensitive to in-cloud scavenging parameters when using SALSA.

Our baseline simulation predicted global PMOM emissions of $1.1 \mathrm{Tg} \mathrm{yr}^{-1}$ (sensitivity range $0.5-1.8 \mathrm{Tg} \mathrm{yr}^{-1}$; see Table 5). This value was well in the range of $0.1-11.9 \mathrm{Tg} \mathrm{yr}^{-1}$ simulated by Gantt et al. (2012), who compared six different ways to estimate the organic mass fraction of sea spray aerosol emissions. It should be noted, however, that the simulated PMOM emissions are sensitive to the choice of sea spray aerosol source function, and that the sea salt emissions 
Table 5. Global total sea spray aerosol emissions and burdens in the model runs. Here SS refers to sea salt and PMOM to primary marine organic matter.

\begin{tabular}{lcccc}
\hline Model run & $\begin{array}{c}\text { SS emission } \\
\left(\mathrm{Tg} \mathrm{yr}^{-1}\right)\end{array}$ & $\begin{array}{c}\text { PMOM emission } \\
\left(\mathrm{Tg} \mathrm{yr}^{-1}\right)\end{array}$ & $\begin{array}{c}\text { SS burden } \\
(\mathrm{Tg})\end{array}$ & $\begin{array}{c}\text { PMOM burden } \\
(\mathrm{Gg})\end{array}$ \\
\hline ossa-ref & 805 & 1.1 & 2.9 & 9.0 \\
ossa-salt & 807 & 0 & 2.9 & 0 \\
default-salt & 7229 & 0 & 12.9 & 0 \\
ossa-lowflux & 378 & 0.5 & 1.2 & 3.5 \\
ossa-highflux & 1233 & 1.8 & 4.6 & 14.6 \\
ossa-low-ics & 805 & 1.1 & 2.9 & 9.6 \\
ossa-high-ics & 806 & 1.1 & 2.9 & 8.8 \\
\hline
\end{tabular}

predicted in Gantt et al. (2012) are even lower than the ones obtained in this study. The estimated magnitude of submicron PMOM emissions in other previous studies were typically much higher than we simulated here, in the range of 2.8-76 $\mathrm{Tg} \mathrm{yr}^{-1}$ (Gantt et al., 2011; Vignati et al., 2010; Mezkhidze et al., 2011; Tsigaridis et al., 2013).

While one reason for the relatively low PMOM emissions in the current study was the extended OSSA source function, which gave sea spray aerosol emissions at the lower end of the published range, it should be noted that most of the previously published estimates have assumed that the organic mass fraction in the emitted sea spray aerosol is determined solely by the chlorophyll $a$ concentration. Gantt et al. (2011) showed, however, that there is a clear inverse correlation between the organic mass fraction and the wind speed, as high winds result in mixing of the organic-enriched surface layer with below-surface waters. The parameterization used in this study (Eq. 3) takes this effect into account through the use of the Rinaldi et al. (2013) parameterization, leading to low organic fractions in high-wind-speed regions even when the chlorophyll $a$ concentration is high $\left(\sim 1 \mathrm{mg} \mathrm{m}^{-3}\right)$ (Fig. 2). Regionally, the reduction of the organic fraction with increasing wind speed was most evident in the Southern Ocean, where wind speeds are high (on average about $10 \mathrm{~m} \mathrm{~s}^{-1}$ ) but the organic fraction was mostly below $2.5 \%$ also between December and February (Fig. 3c). Note that the formation of PMOM was based on the Rinaldi et al. (2013) parameterization which was derived using data from the North Atlantic but has not been evaluated for other regions due to lack of representative experimental data. In the simulation ossa-ref, the global mean organic mass fraction in the dry diameter range of 30-700 nm of sea spray aerosol emissions was only about $4 \%$, with values exceeding $20 \%$ only along coastlines (Fig. 3c and d).

As expected, the largest sea salt emissions were seen in southern mid-latitudes (Figs. 3a and 4a) where the surfacelevel wind speeds are consistently high throughout the year. Another region with high sea salt emissions was the northern mid-latitudes (Fig. 3a), especially in the winter months (Fig. 4a). However, the emissions in this region showed large

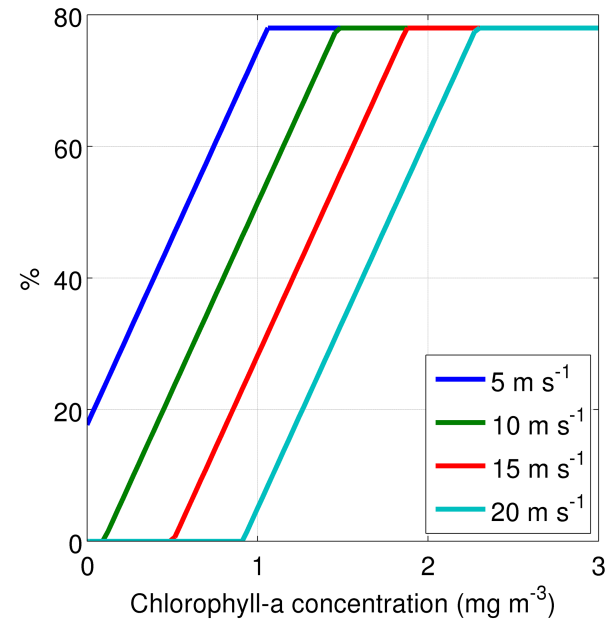

Figure 2. Dependence of organic mass fraction of sea spray emissions (Rinaldi et al., 2013) on the oceanic chlorophyll $a$ concentration and $10 \mathrm{~m}$ wind speed.

seasonal variation. Across these latitude bands, the sea salt fluxes were typically lowest in the summer months (Fig. 4a). This implies that the seasonal changes in wind speed are much more important than seasonal changes in sea surface temperature in terms of determining the total sea spray aerosol flux.

Despite the small organic fraction in emitted sea spray aerosol in the southern mid-latitudes, some of the highest marine PMOM emissions in terms of mass were seen in this region (Figs. $3 \mathrm{~b}$ and $4 \mathrm{c}$ ). This was due to the very high total sea spray aerosol emissions in these high wind speed regimes. Another prominent source region of PMOM was the Northern Hemisphere mid-latitudes, where emissions were especially high in the autumn months (Fig. 4c). Comparing Fig. $4 \mathrm{a}$ and $\mathrm{c}$, it is evident that the seasonality and zonal patterns of sea salt and PMOM differed quite a lot. PMOM showed a strong seasonal variation due to the seasonality of biological activity, especially polewards of $\pm 50^{\circ}$ latitude, while the seasonal variation of the sea salt emissions was largest in the mid-latitudes and Southern Hemisphere tropics. 
a)

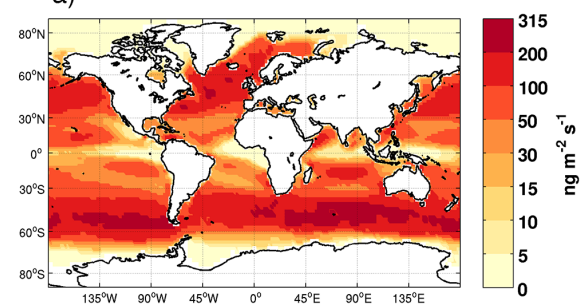

c)

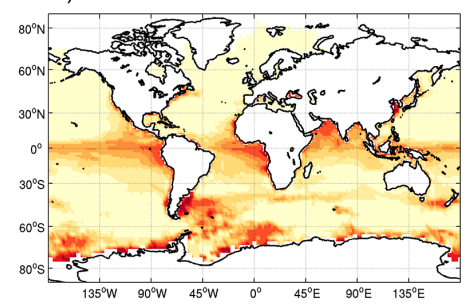

b)

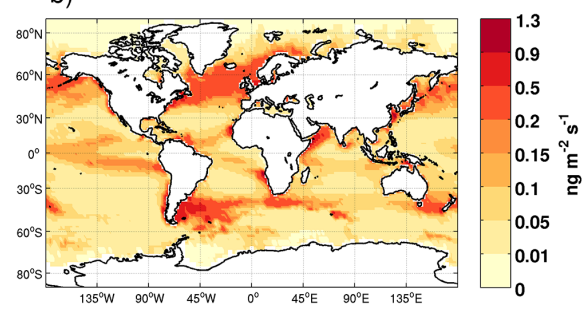

d)

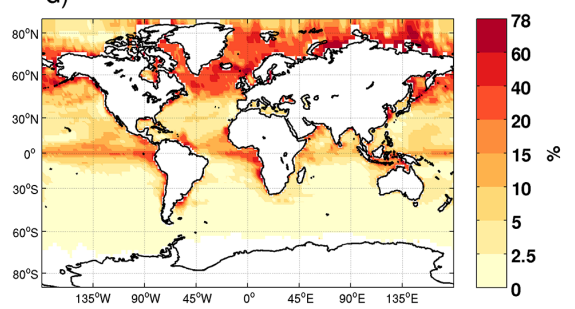

Figure 3. Annual mean emissions (2006-2010) of (a) sea salt aerosol and (b) primary marine organic matter (PMOM) in sea spray aerosol, (c) the mass fraction (in the dry diameter range of 30-700 nm) of PMOM in sea spray aerosol emissions during December-January-February, and (d) the mass fraction of PMOM in sea spray aerosol emissions during June-July-August.
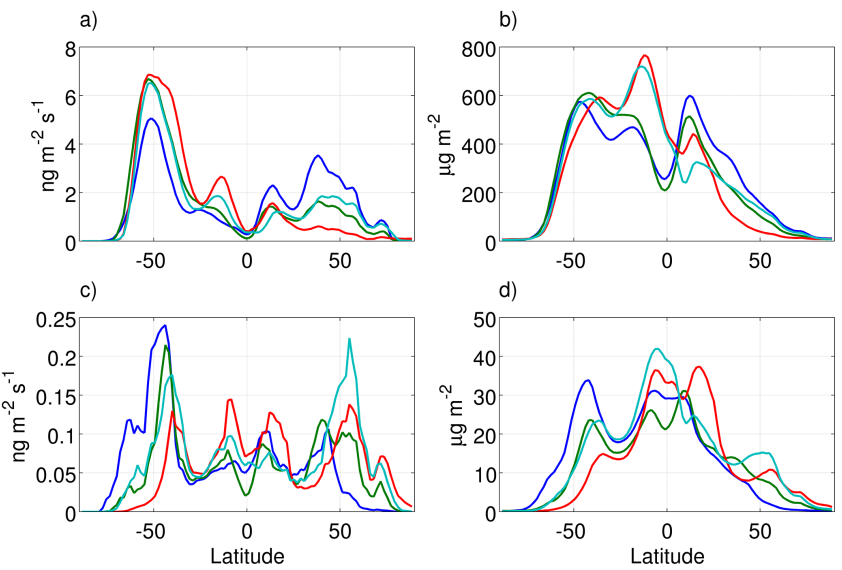

-DJF - MAM - JJA - SON

Figure 4. Seasonal zonal means of (a) emissions of sea salt, (b) burden sea salt, (c) emissions of primary marine organic matter, and (d) burden of primary marine organic matter. DJF, MAM, JJA, and SON stand for mean over December-January-February, March-April-May, June-July-August, and September-October-November, respectively.

Furthermore, whereas the contribution of low latitudes to global sea salt emissions was small, a significant fraction of PMOM was emitted from these regions, especially in the boreal summer months.

It is also worth noting that the simulated sea spray aerosol emissions (Fig. 4a and c) and burdens (Fig. 4b and d) showed very different zonal behaviour. For example, while the emissions of both sea salt and PMOM were relatively low at low latitudes compared to the mid-latitudes, the burdens of both compounds peaked in the Tropics due to significantly slower removal in that region and possibly transport of sea spray from the higher latitudes. The difference in the spatial patterns of sea spray burdens and emissions imply that it is very difficult to use in situ measurements of sea spray aerosol mass or remote sensing measurements of AOD to directly deduce information about the magnitude of local sea spray emissions.

\subsection{Comparison to in situ measurements}

We compared the simulated aerosol mass concentrations and size distributions obtained using the extended OSSA source function with the high-quality long-term observations available from one marine (Amsterdam Island) and two coastal (Mace Head, Point Reyes) sites as described in Sect. 2.4 and Fig. 1.

The Mace Head station on the west coast of Ireland makes measurements of the $\mathrm{PM}_{1}$ concentrations of sulfate, sea salt and organic matter, and of the aerosol size distribution. The cut-off size of $1 \mu \mathrm{m}$ in the $\mathrm{PM}_{1}$ measurements was based on vacuum aerodynamic diameter, i.e. $D_{\mathrm{va}}=0.8 \cdot D \cdot(\rho / 1000)$, where $D$ is modelled particle diameter and $\rho$ is particle density. Since the grid cell containing the exact location of the Mace Head station is defined as "land" in the model, and thus included continental emissions but not sea spray aerosol emissions, we used the adjacent grid cell to the west of the site in our comparison with in situ measurements. This grid cell is defined as "sea" in the model and showed about $40 \%$ higher sea salt concentrations compared to the grid cell containing the exact Mace Head location.

Figure 5 shows the monthly mean sulfate, sea salt, and total organic matter (both continental and $\mathrm{PMOM}$ ) $\mathrm{PM}_{1}$ 

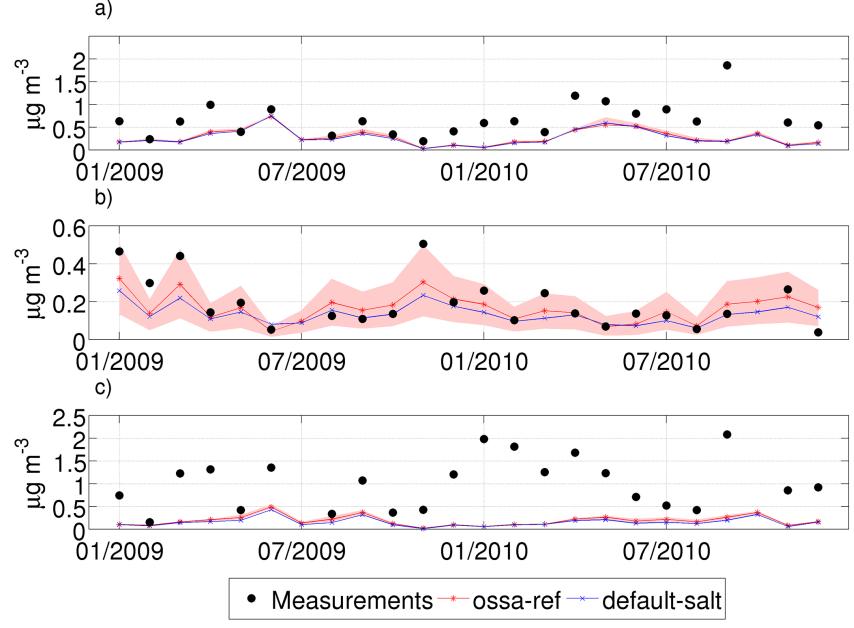

Figure 5. Monthly mean $\mathrm{PM}_{1}$ mass concentration of (a) sulfate, (b) sea salt and (c) organic matter in the in situ measurements at Mace Head and in the model. The shading around the red line (ossa-ref) indicates the spread of the model results from the sensitivity simulations. The model $\mathrm{PM}_{1}$ concentration was calculated by integrating the size distribution up to $1 \mu \mathrm{m}$ in terms of vacuum aerodynamic diameter (see text).

concentrations in Mace Head for the years 2009 and 2010. The sea salt concentration at this site was captured well by the model with both the extended OSSA source function and the default sea salt source function in ECHAM-HAMMOZ (simulations ossa-ref and default-salt, respectively): the measured sea salt concentration fell within the simulated uncertainty range of the extended OSSA source function (defined by the sensitivity simulations ossa-highflux, ossa-lowflux, ossa-high-ics, and ossa-low-ics) in 19 out of 22 months with measurement data available. However, on average the simulation ossa-ref tended to underestimate sea salt concentrations slightly (normalized mean bias of $-13 \%$, correlation coefficient of 0.83 ).

On the other hand, the sulfate and organic matter concentrations were underestimated for most of the months during the comparison period (normalized mean biases of -59 and $-82 \%$, respectively). Whereas the model seemed to have some skill in predicting the seasonal variation of sulfate, the same was not true for organic matter (correlation coefficient of 0.17). Note that both the measured and the simulated sulfate and organic matter concentrations shown in Fig. 5 also include material emitted from continental sources (only $15 \%$ of the modelled organic matter was PMOM on 2-year average at Mace Head). Therefore, some of the poor match between the model and observations is likely to have arisen from uncertainties in continental emissions. Even in the summer time, when the organic fraction of sea spray aerosol peaks according to the measurements (e.g. O'Dowd et al., 2004), $80 \%$ of the modelled organic matter concentration originated from continental sources. Therefore, it seems

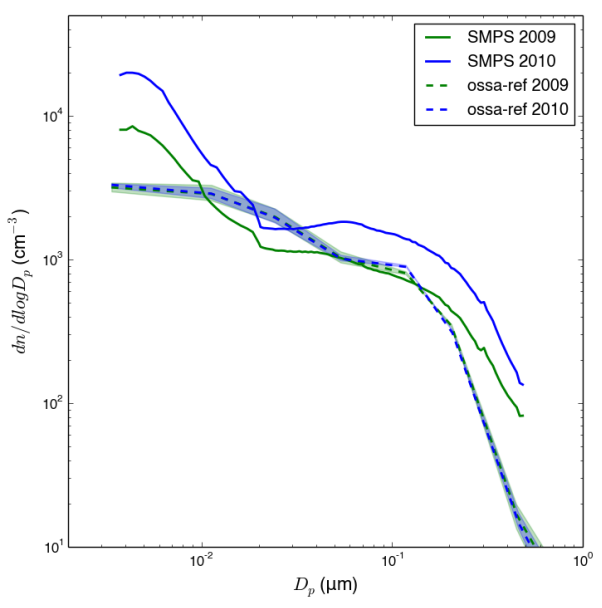

Figure 6. Annual mean measured and modelled size distribution at Mace Head. The modelled values are for the references simulation ossa-ref (solid line) and the spread is given by the sensitivity simulations (shading).

likely that the parameterization used in the study for predicting the organic fraction of the sea spray aerosol (Rinaldi et al., 2013) is unable to capture all the nuances of PMOM emissions.

Figure 6 shows the observed (solid lines) and modelled (dashed lines) annual mean size distributions at Mace Head for years the 2009 and 2010. The model captured the size distribution reasonably well between $20-200 \mathrm{~nm}$, but underestimated the size distribution below $20 \mathrm{~nm}$ and above $200 \mathrm{~nm}$. The underestimation of the nucleation mode was expected, since the model included only activation nucleation of sulfuric acid (Kulmala et al., 2006) while previous observations from Mace Head have suggested that iodine nucleation is likely to play an important role at this site (O'Dowd et al., 2002). The underestimation of the large accumulation mode particles was likely caused mostly by the poor model skill in simulating the aerosol organic matter content (see Fig. 5c), although uncertainties in simulating the sulfate and sea salt aerosol sources may also have contributed to some extent.

Figure 7 depicts the modelled mass concentrations at Amsterdam Island together with measurements of sodium ion $\left(\mathrm{Na}^{+}\right)$mass concentration in three size classes $\left(\mathrm{PM}_{1}\right.$, $\mathrm{PM}_{1-2.5}$, and $\mathrm{PM}_{2.5-10}$ ), and total carbonaceous aerosol concentration for $\mathrm{PM}_{1}$ (using the aerodynamic diameter: $D_{\mathrm{a}}=$ $\left.D \cdot(\rho / 1000)^{1 / 2}\right)$. Overall, the model somewhat underestimated (normalized mean bias of $-52 \%$, correlation coefficient of 0.75) sodium ion mass concentration in $\mathrm{PM}_{1}$ (Fig. 7a), but clearly overestimated it in larger sizes (Fig. 7b and c). However, the extended OSSA source function provided a clear improvement compared to the default sea salt source function (simulation default-salt) in all three size ranges. In the largest size range, $\mathrm{PM}_{2.5-10}$, the normalized mean bias was reduced from $4519 \%$ in defaultsalt to $899 \%$ in ossa-ref. As at Mace Head, the model 

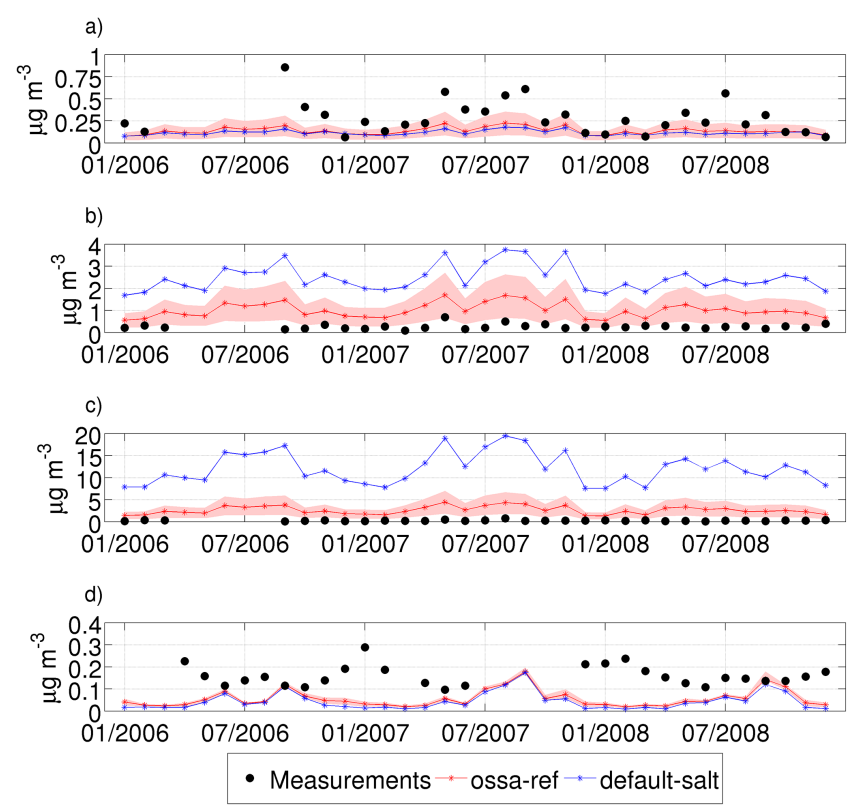

Figure 7. Measured and modelled monthly mean mass concentration of the sodium ion in three different size ranges: (a) $\mathrm{PM}_{1}$, (b) $\mathrm{PM}_{1-2.5}$, and (c) $\mathrm{PM}_{2.5-10}$, and (d) total carbonaceous aerosol (in $\mathrm{PM}_{1}$ ) at Amsterdam Island. The shaded area around the red line corresponding to ossa-ref represents the uncertainty from the sensitivity runs.

underestimated (normalized mean bias of $-68 \%$, correlation coefficient of -0.45 ) the total carbonaceous aerosol concentration (Fig. 7d). The underestimation was largest during the summer months, when the contribution of PMOM is expected to be largest. The total carbonaceous aerosol concentration in the model consisted of $72 \%$ continental organic matter, only $21 \%$ PMOM, and $8 \%$ black carbon. In the summer time, the modelled monthly mean fraction of PMOM of total carbonaceous aerosol peaked at $59 \%$. The fraction of PMOM was significantly less than was predicted by e.g. Vignati et al. (2010), who calculated that the average primary marine fraction of organic carbon in the Southern Ocean in January and July would be more than 90 and $80 \%$, respectively. The large relative contribution of continental emissions to total carbonaceous aerosol in our study was caused by the low emissions of PMOM, not high continental contribution in absolute terms as total carbonaceous aerosol was underestimated.

Figure 8 shows the observed and modelled $\mathrm{PM}_{2.5}$ (in terms of aerodynamic diameter) mass concentrations of sulfate, sea salt, and total (both continental and PMOM) organic matter for the years 2006-2010 at Point Reyes, which is located on the west coast of the US. Unlike Mace Head, the location of Point Reyes is defined as "sea" in the model, so we used the grid cell containing Point Reyes for comparisons. The model run with the extended OSSA source function captured the monthly mean values of observed sea
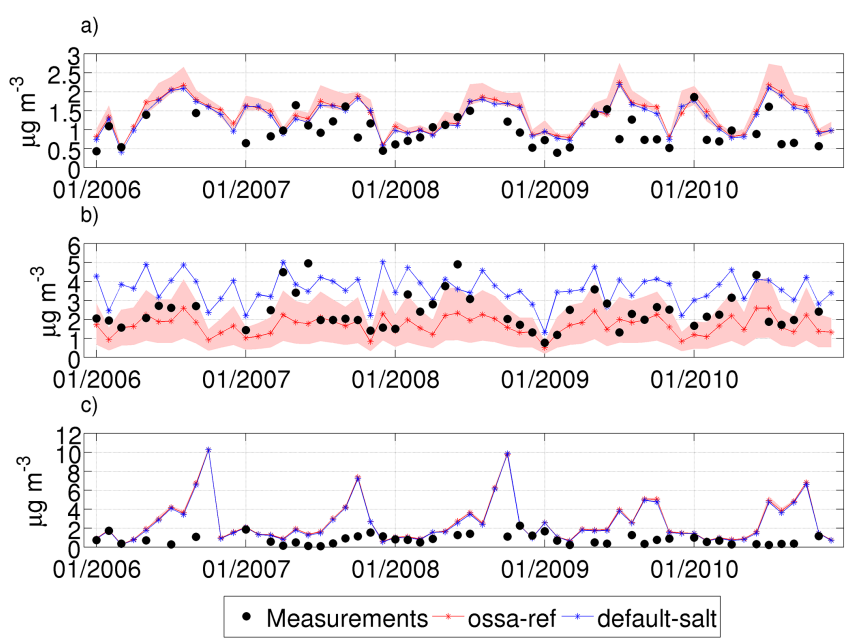

Figure 8. Measured and modelled monthly mean $\mathrm{PM}_{2.5}$ mass concentration of (a) sulfate, (b) sea salt and (c) organic matter at Point Reyes. The shaded area around the red line corresponding to simulation ossa-ref represents the uncertainty from the sensitivity runs.

salt concentrations well, with $70 \%$ of the observed monthly mean values falling within the modelled uncertainty range (Fig. 8b). The extended OSSA source function showed also a clear improvement over the default-salt run, with the normalized mean bias reduced from 50 to $-29 \%$ (correlation coefficients were 0.55 in both). The sulfate mass concentration and its seasonal variability were also reproduced fairly well by the model (Fig. 8a). The organic carbon mass concentration was overestimated (normalized mean bias $212 \%$, correlation coefficient 0.14 ) in the model, especially in the summer months (Fig. 8c). As with the other two stations, the contribution of PMOM from sea spray aerosol emissions was very small at Point Reyes (monthly mean fraction of PMOM of total organic matter was $0.3-8 \%$ ). Thus, the overestimation of organic matter was caused by continental sources.

Figure 9 shows a comparison between simulated (ossa-ref) and observed (EMEP) monthly mean values of sodium ion concentration in $\mathrm{PM}_{2.5}$ and $\mathrm{PM}_{10}$. Figure 9a shows a clear underestimation (normalized mean bias of $-66 \%$ ) of the largest observed $\mathrm{PM}_{2.5}$ monthly mean values. There were no clear seasonal differences present in the observed values, but simulated winter values were larger than summer values. There was an even stronger seasonal dependence in $\mathrm{PM}_{10}$ in the model (Fig. 9b). Measured and modelled $\mathrm{PM}_{10}$ values also agreed better during the summer months (normalized mean bias of $5 \%$ ), but in the winter the model clearly overestimated (normalized mean bias of $46 \%$ ) the sodium ion concentration. All-year normalized mean bias for $\mathrm{PM}_{10}$ in ossa-ref was $32 \%$. The correlation of $\mathrm{PM}_{2.5}$ was weak (0.03) but better (0.55) for $\mathrm{PM}_{10}$ in ossa-ref.

Both $\mathrm{PM}_{2.5}$ and $\mathrm{PM}_{10}$ concentrations were overestimated using the model default sea spray source function (Fig. S1 in the Supplement; normalized mean biases of 38 and $84 \%$, 

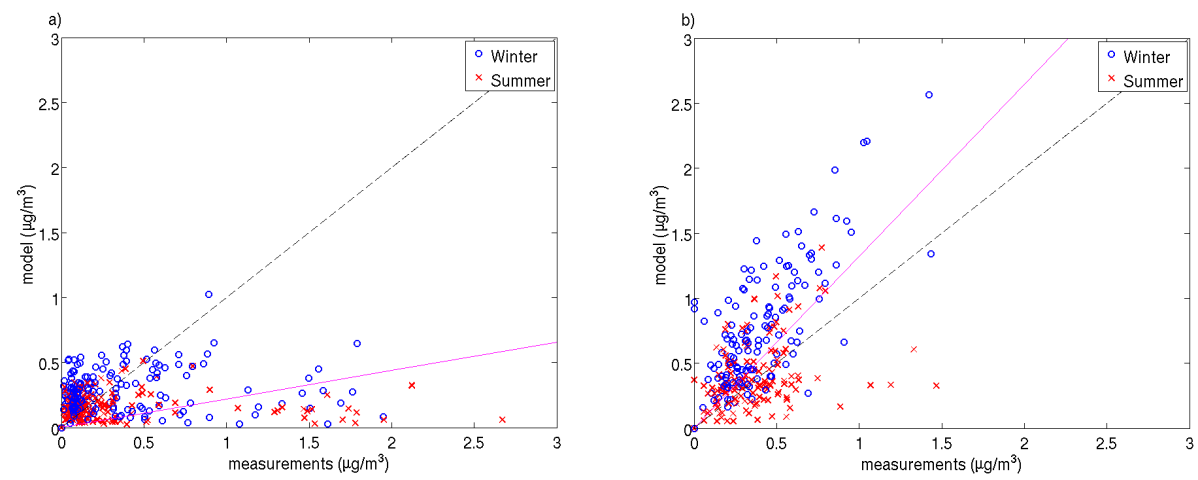

Figure 9. Comparison of measured (EMEP stations) and modelled (simulation ossa-ref) monthly mean sodium ion concentration in (a) $\mathrm{PM}_{2.5}$ and (b) $\mathrm{PM}_{10}$ at various sites for the years 2006-2011. Blue circles indicate boreal winter months (October-March) and red crosses indicate boreal summer months (April-September). The violet line is the linear regression line for all months.

respectively, in default-salt). The correlations of $\mathrm{PM}_{2.5}$ and $\mathrm{PM}_{10}$ between the model and the measurements were slightly better in default-salt than in ossa-ref (0.14 and 0.60).

Overall, the extended OSSA source function decreased the magnitude of normalized mean bias in sea spray aerosol concentrations. There was however a small decrease in the correlation coefficients. See Table S1 in the Supplement for more details on the comparison of results between ossa-ref and default-salt.

It is difficult to compare simulated values with point measurements, as the model cannot capture the subgrid-scale variability in aerosol concentrations. All except one of the measurement stations are located in grid boxes classified as "land", meaning that there were no sea spray aerosol emission sources within the stations' grid boxes. Some measurement stations are located quite near the coast, but stations which are further inland can better represent modelled conditions as sea salt concentration gradients (and thus the sensitivity to grid cell selection) were highest near the coasts.

\subsection{Comparison to AOD measurements}

The modelled AOD values (at a wavelength of $550 \mathrm{~nm}$ ) over the oceans were compared with satellite-retrieved AOD fields (Fig. 10a). It has previously been shown that ECHAMHAMMOZ-SALSA using the default sea spray aerosol source function (corresponding to our simulation defaultsalt) tends to overestimate the oceanic AOD derived from MODIS/MISR in the Tropics and to underestimate at high latitudes (Bergman et al., 2012). This can be seen also in Fig. 10c, which shows the annual normalized mean bias between AOD calculated in the default-salt simulation and AOD retrieved from PARASOL satellite measurements. On average, the default-salt simulation predicted an AOD which is $13 \%$ higher over the ocean than PARASOL retrievals.

When the default source function was replaced by the extended OSSA source function (simulation ossa-ref), the satellite-retrieved AOD was underestimated over most oceanic regions (Fig. 10b). As a result, the normalized mean bias over the oceans was $-31 \%$. While the absolute value of the normalized mean bias to PARASOL was clearly smaller when using the default sea spray aerosol source function $(13 \%$, Fig. 10c) than the extended OSSA source function $(-31 \%$, Fig. 10b), this was mainly due to the large compensating over- and underestimations in different parts of the world when using the default source function. Normalized mean errors for ossa-ref and default-salt were 35 and $41 \%$, respectively, showing that overall, the extended OSSA source function improved the results. The extended OSSA source function significantly improved the agreement between model and measurements in the Tropics and midlatitudes, although it deteriorated somewhat at high latitudes (where satellite observations have the least coverage). The PARASOL values fell within the uncertainty range from ossa-highflux and ossa-lowflux across $36 \%$ of the ocean's area (shaded area in Fig. 10b). The model performed especially well in marine regions from the equator to $45^{\circ} \mathrm{S}$, which represent some of the least polluted oceanic regions in the world, and are therefore dominated by natural aerosol emissions.

We made a more detailed evaluation of the modelpredicted AOD against PARASOL data over the Southern Ocean $\left(30-60^{\circ} \mathrm{S}\right)$ and in proximity to the three stations discussed in Sect. 3.2 (see the ocean masks used in Fig. 1). Over the Southern Ocean, the extended OSSA source function tended to underestimate the satellite-retrieved AOD even when the uncertainty range is accounted for (Fig. 11a, compare black line with red line and shading). It is also apparent that the seasonal cycle in AOD was shifted compared to the measurements: whereas the peak monthly mean values were observed in the spring months, the model predicted the highest values in the middle of the summer. However, compared to the default sea spray aerosol source function in ECHAM-HAMMOZ (simulation default-salt), the extended OSSA source function provided some improvement in simulating AOD over this region. 


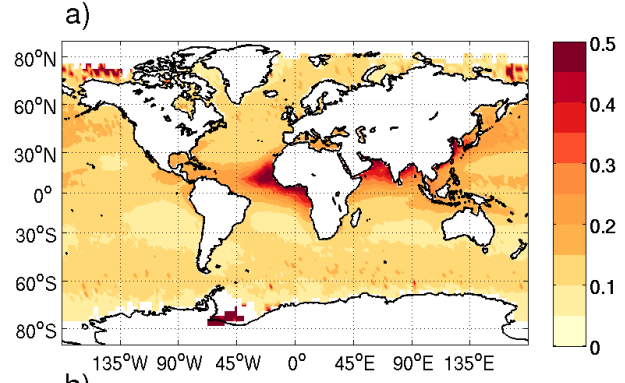
b)

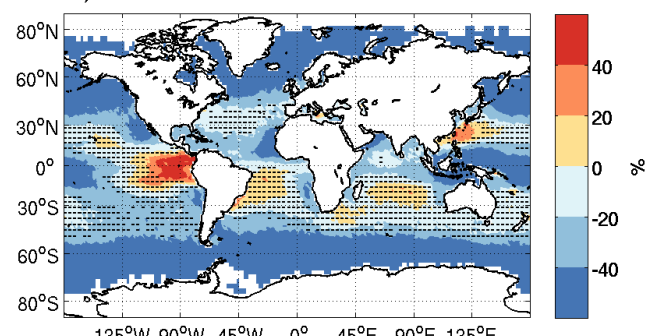

c)

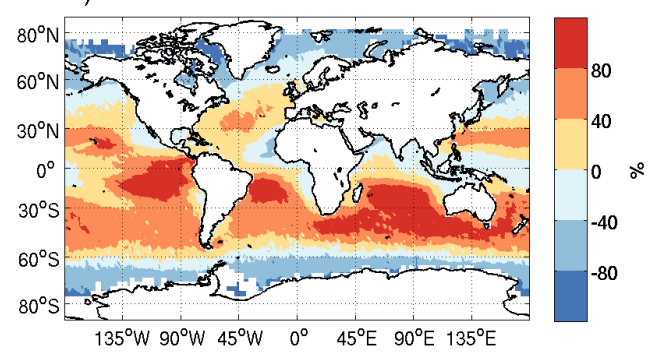

Figure 10. Comparison of modelled 5-year-mean AOD fields to 5-year-mean satellite-retrieved observations from PARASOL. The panels show (a) the observed AOD, and the normalized mean bias (with respect to PARASOL AOD) in the simulations (b) ossa-ref and (c) default-salt. The shaded area in (b) represents area where AOD from PARASOL was within the OSSA sensitivity range. The normalized mean bias ranged spatially between -100 and $138 \%$, and between -100 and $168 \%$ in ossa-ref and in default-salt, respectively.

Around Amsterdam Island, the model captured the magnitude and also much of the seasonal variability of the observed AOD (Fig. 11b). The measured monthly AOD fell within the simulated uncertainty range (red shading) for all but six months (out of 60). However, there was a slight decreasing trend in the measured AOD which the model was unable to reproduce; as a result, the agreement between the baseline simulation ossa-ref and the measurement improved towards the end of the simulated period. Part of the good match between the modelled and measured AOD in this region is probably explained by underestimation of small particles and overestimation of large particles (Fig. 7) compensating the error of each other. Over this region, the model predicted that $69 \%$ of the AOD is from sea spray aerosol (the difference between the solid red and dashed black lines relative to the solid red line in Fig. 11b). The default sea spray aerosol source
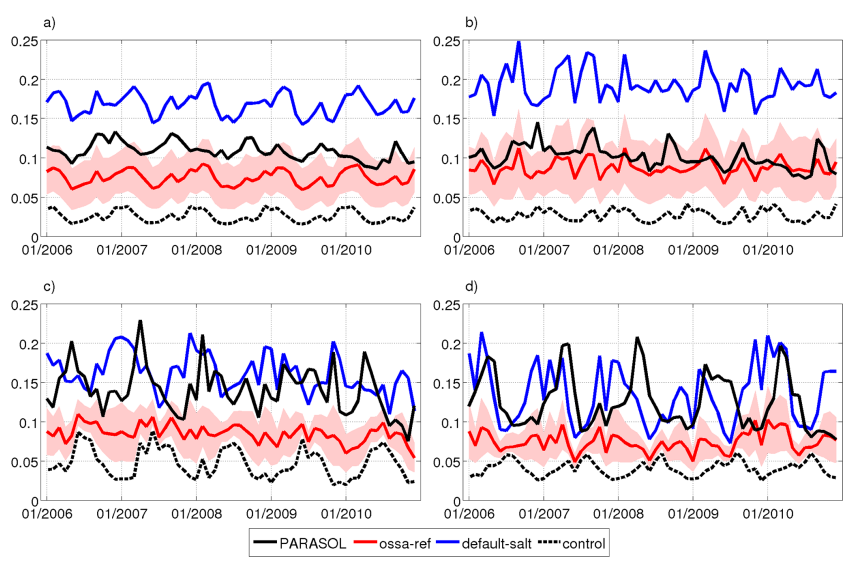

Figure 11. Satellite-retrieved (PARASOL) and modelled monthly mean AOD values (a) over the Southern Ocean, (b) around Amsterdam Island, (c) west of Mace Head and (d) west of Point Reyes (see Fig. 1).

function in ECHAM-HAMMOZ (default-salt) predicted almost twice the observed AOD values (solid blue line).

Around Mace Head and Point Reyes, both of which are much more heavily influenced by continental emissions than Amsterdam Island, the modelled AOD values in the ossaref run were clearly lower than the measured ones (Fig. 11b and c, respectively). At both sites, the model captured some features of the observed seasonal variation (correlation coefficients of 0.32 and 0.13 for Mace Head and Point Reyes, respectively) but underestimated most of the monthly peak values in winter/early spring by over $50 \%$ or by absolute AOD value 0.1 . It is worth noting that at both of these sites, the default-salt run gave a much better match with the measurements than ossa-ref. However, our comparison with in situ mass concentrations (Fig. 5) suggests that the underestimation of AOD in ossa-ref at Mace Head may be due to poor model performance in predicting the PMOM rather than the sea salt emissions.

We also compared the modelled monthly mean AOD to AERONET measurements (500 nm interpolated to $550 \mathrm{~nm}$ ) at 17 island and 24 coastal stations (Fig. 12). The model showed reasonably good skill in all seasons, with correlation coefficients of $0.80,0.83,0.66$, and 0.70 for boreal winter, spring, summer, and autumn months respectively. The normalized mean biases (normalized mean errors) for the seasons were $15 \%(42 \%),-29 \%(40 \%),-24 \%(40 \%)$, and $-12 \%(36 \%)$ for boreal winter, spring, summer, and autumn months, respectively. The simulation default-salt had slightly larger normalized mean biases than ossa-ref ( $-16 \%$ vs. $8 \%$ for coastal stations and $19 \%$ vs. $-16 \%$ for island stations. All-year correlation was slightly higher in default-salt than in ossa-ref for coastal stations (0.91 vs. 0.83 ) and slightly lower for island stations (0.67 vs. 0.74). See Table S1 for more details. 


\section{Radiative effects of sea spray aerosol particles}

The radiative effects of sea spray aerosol particles were estimated from the difference between all-sky top-ofatmosphere net total radiation in each of the sea spray simulations and in the control run. This method yields an effective radiative forcing (ERF) (also known as radiative flux perturbation) which includes both direct and indirect effects (Haywood et al., 2009). The all-sky direct radiative effect (direct component of ERF) of sea spray aerosol particles was calculated as follows: first, the radiation routine during each time step was called with and without aerosol. The difference in total net radiation between these calls was taken as the total (including all aerosols) aerosol direct effect of a given model run. Then, the direct radiative effect of sea spray aerosol particles was calculated from the difference in total aerosol direct effect between a sea spray simulation and the control run. The total indirect effect (indirect component of ERF) of sea spray aerosol particles was calculated by subtracting the direct radiative effect from the ERF (semi-direct effect of sea spray aerosol is negligible due to low absorption).

Table 6 summarizes the simulated global mean radiative effects of sea spray aerosol particles in the different runs. All our simulations predicted a negative ERF due to sea spray aerosol particles (i.e. total cooling effect); however, the runs using the extended OSSA source function showed much lower values $\left(-0.20 \mathrm{~W} \mathrm{~m}^{-2}\right.$ in the baseline run ossa-ref, with a sensitivity range from -0.10 to $-0.37 \mathrm{~W} \mathrm{~m}^{-2}$ ) than the run using the default sea spray aerosol source function in ECHAM-HAMMOZ $\left(-0.64 \mathrm{~W} \mathrm{~m}^{-2}\right.$ in simulation defaultsalt). Furthermore, our baseline simulation ossa-ref gave a direct all-sky radiative effect of $-0.50 \mathrm{~W} \mathrm{~m}^{-2}$ (sensitivity range from -0.21 to $-0.77 \mathrm{~W} \mathrm{~m}^{-2}$ ) (Table 6). This is in good agreement with previously published estimates: for example, Reddy et al. (2005) obtained a direct sea spray aerosol radiative effect of $-0.3 \mathrm{~W} \mathrm{~m}^{-2}$, whereas Ma et al. (2008) predict an all-sky value of $-0.6 \mathrm{~W} \mathrm{~m}^{-2}$. The direct all-sky radiative effect in our run default-salt was $-1.17 \mathrm{~W} \mathrm{~m}^{-2}$, the absolute value of which is clearly larger than many previously published estimates. On the other hand, the global mean clearsky direct effect in ossa-ref was $-0.84 \mathrm{~W} \mathrm{~m}^{-2}$, which is also in the range of estimates from previous studies. It is, for example, higher (in magnitude) than $-0.44 \mathrm{~W} \mathrm{~m}^{-2}$ calculated by Rap et al. (2013), but lower than $-1.5 \mathrm{~W} \mathrm{~m}^{-2}$ calculated by Ayash et al. (2008).

Rather surprisingly, our simulations predicted a positive total indirect effect (i.e. warming effect due to interactions with clouds) for sea spray aerosol. The baseline run gave a value of $0.30 \mathrm{Wm}^{-2}$ (sensitivity range $0.11-0.40 \mathrm{~W} \mathrm{~m}^{-2}$ ), which was lower than in the run using the ECHAM-HAMMOZ default sea spray aerosol source function $\left(0.53 \mathrm{~W} \mathrm{~m}^{-2}\right.$ in default-salt $)$. Our results contrast with several previous global modelling studies, which have obtained a negative total indirect radiative effect for sea spray aerosol particles, such as the value of $-2.9 \mathrm{~W} \mathrm{~m}^{-2}$ from the
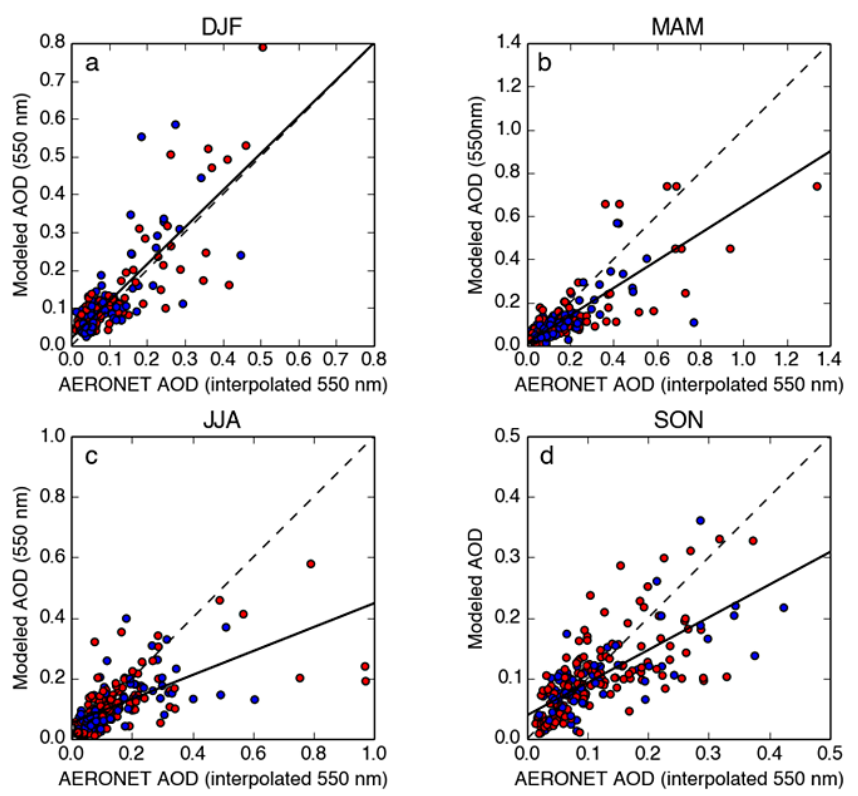

- Island stations $\quad \bullet \quad$ Coastal stations

Figure 12. Comparison of observed (AERONET) and modelled (ossa-ref) monthly mean AOD in (a) December-January-February (DJF), (b) March-April-May (MAM), (c) June-July-August JJA) and (d) September-October-November (SON). The comparison includes the AERONET island and coastal stations which had data available in the years 2006-2010. The solid black line is the linear regrssion line for all stations.

Table 6. Global mean radiative effects (5-year means) in the model runs. ERF stands for effective radiative forcing.

\begin{tabular}{lccc}
\hline Model run & $\begin{array}{c}\mathrm{ERF} \\
\left(\mathrm{W} \mathrm{m}^{-2}\right)\end{array}$ & $\begin{array}{c}\text { Direct effect } \\
\left(\mathrm{W} \mathrm{m}^{-2}\right)\end{array}$ & $\begin{array}{c}\text { Indirect effect } \\
\left(\mathrm{W} \mathrm{m}^{-2}\right)\end{array}$ \\
\hline ossa-ref & -0.20 & -0.50 & 0.30 \\
ossa-salt & -0.15 & -0.53 & 0.37 \\
default-salt & -0.64 & -1.17 & 0.53 \\
ossa-lowflux & -0.10 & -0.21 & 0.11 \\
ossa-highflux & -0.37 & -0.77 & 0.40 \\
\hline
\end{tabular}

study of Ma et al. (2008). The positive indirect effect was most evident in the Southern Ocean (Fig. 13c). In the same region, there was a clear decrease in the cloud droplet number concentration (CDNC) burden between runs ossa-ref and $\mathrm{ctrl}$ (Fig. 14a). This suggests two likely reasons for the positive indirect effect in our simulations. First, large sea salt particles take up so much water that they decrease the maximum supersaturation and thus prevent smaller particles from activating (Ghan et al., 1998; O'Dowd et al., 1999a, b; Gong and Barrie, 2003; Korhonen et al., 2010). Second, sea salt particles also act as a condensation sink for sulfuric acid, which reduces nucleation and the condensation of sulfuric acid onto nucleation mode and other sub-CCN particles (Gong and 
a)

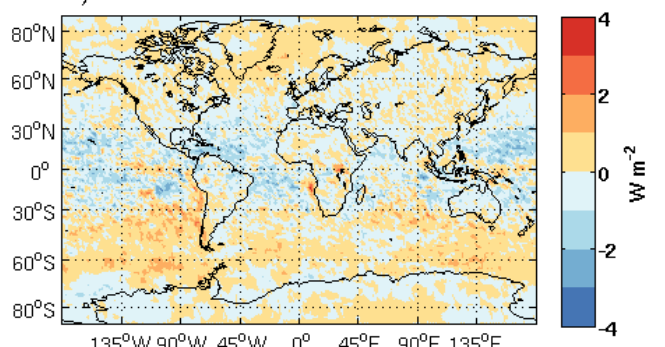
b)

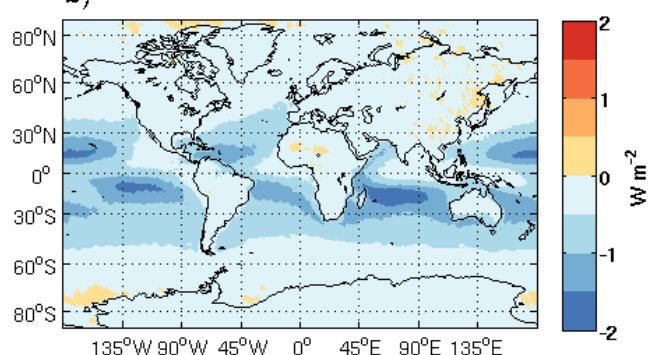
c)

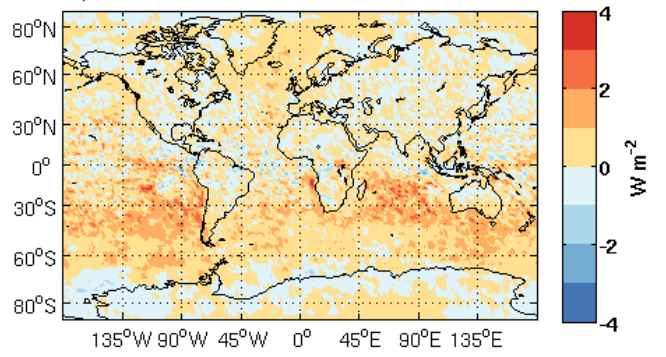

Figure 13. Radiative effects (5-year means) of sea spray aerosol in simulation ossa-ref. (a) Effective radiative forcing (total effect), (b) direct effect, (c) indirect effect.

Barrie, 2003; Korhonen et al., 2010). The effect of these two mechanisms on the positive indirect effect is supported by the fact that there were clearly fewer particles in the model size bins below $145 \mathrm{~nm}$ in ossa-ref than in ctrl (Fig. 15a). While slightly more large sea spray particles (dry diameter above $145 \mathrm{~nm}$ ) activated in ossa-ref compared to $\mathrm{ctrl}$, the lower number of activated small particles (below $145 \mathrm{~nm}$ ) meant that the total CDNC was lower in ossa-ref (Fig. 15b). The total number of soluble particles with dry diameter larger than $30 \mathrm{~nm}$ was $7 \%$ lower in ossa-ref than in ctrl in the lowest five model levels (up to about $1 \mathrm{~km}$ ) above the ocean. Together, these effects mean that sea spray aerosol emissions may not increase the cloud droplet concentration in the marine atmosphere, even if they increase the emissions of primary CCN.

These results are consistent with those of O'Dowd et al. (1999b) who illustrated that the addition of more $\mathrm{CCN}$ could reduce rather than increase the CDNC if the $\mathrm{CCN}$ properties differed from those of the existing population as in the case of adding sea salt $\mathrm{CCN}$ to an existing sulfate CCN population. O'Dowd et al. (1999b) reported also that sea salt can increase CDNC in very clean air with low sulfate concentration, but we did not find this effect by analysing the annual mean data from the simulation ossa-ref. Even though the mean sulfate concentration in the accumulation mode $\left(0.1 \mu \mathrm{m}<D_{\text {dry }}<1 \mu \mathrm{m}\right)$ over the Southern Ocean $\left(\sim 70 \mathrm{~cm}^{-3}\right)$ was less than half the switchover point for decreased CDNC $\left(\sim 150 \mathrm{~cm}^{-3}\right)$ estimated by O'Dowd et al. (1999b), the high modelled updraft velocities $\left(>1 \mathrm{~m} \mathrm{~s}^{-1}\right)$ resulted in decreased CDNC also in the Southern Ocean. This result differs from simulations by Ghan et al. (1998) who predicted that low-sulfate and high-updraftvelocity conditions would lead to increased CDNC with sea salt. The difference in results between our study and that of Ghan et al. (1998) may be a result of differences in sea salt or sulfate size distribution as the activation parameterization used by Ghan et al. (1998) (Abdul-Razzak et al., 1998) was very similar to that in this study (Abdul-Razzak and Ghan, 2002).

According to our simulations, PMOM decreased the magnitude of both the direct and indirect radiative effects of sea spray aerosol (Table 6, runs ossa-ref and ossa-salt). As described in Sect. 2.2, PMOM had a very low hygroscopicity in subsaturated conditions, and its cloud activation efficiency was high, but lower than that of sea salt. Although the hygroscopicity of PMOM was lower than that of sea salt, CDNC burden was higher in ossa-ref than in ossa-salt, which had no organic enrichment of sea spray aerosol emissions (Fig. 14b), and the positive indirect effect was $0.07 \mathrm{~W} \mathrm{~m}^{-2}$ lower (Table 6). The most likely reason for this result is that the low hygroscopicity of PMOM decreases the water uptake and thus size of sea spray particles, which in turn decreases the condensation sink of sulfate and enhances nucleation and condensation of sulfate on smaller particles. This was reflected in slightly higher (1-3\% on average over the Southern Ocean) number concentrations, sulfate mass, and activated number of particles with dry diameter smaller than $145 \mathrm{~nm}$. As also the liquid water path over the oceans was slightly higher in ossa-ref than in ossa-salt, other processes in addition to the difference in the sulfate condensation sink probably affect the negative indirect effect of PMOM.

On the other hand, the global mean direct effect of PMOM was $0.03 \mathrm{~W} \mathrm{~m}^{-2}$ (Table 6 , calculated as the difference between ossa-ref and ossa-salt). This slight warming effect from PMOM is due to their lower water uptake compared to sea salt, part of which it is replacing in the ossa-ref simulation compared to ossa-salt. The refractive index of PMOM was similar to that of sea salt at $550 \mathrm{~nm}\left(1.48+10^{-9} \mathrm{i}\right.$ vs. $1.49+10^{-6} \mathrm{i}$ ), so the difference in optical properties has no role in the difference in direct radiative effect.

\section{Summary and conclusions}

We have used a global aerosol-climate model ECHAMHAMMOZ with the microphysics module SALSA to evaluate a new sea spray aerosol source function, which en- 
a)

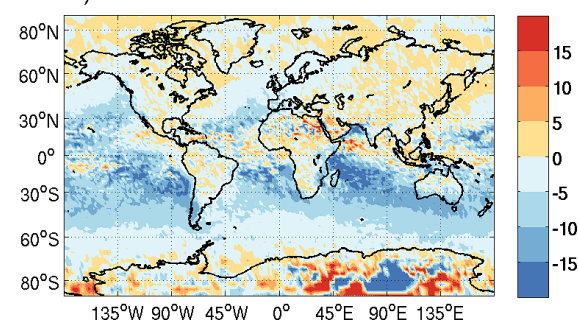

b)

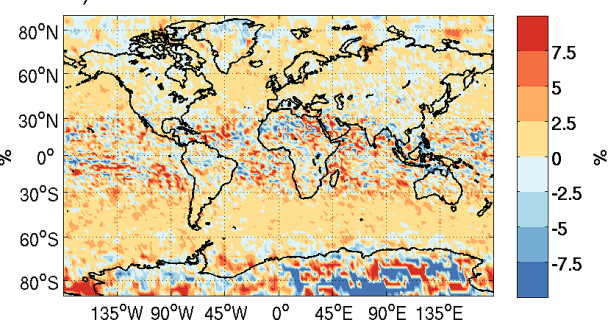

Figure 14. Relative difference in 5-year-mean cloud droplet number burden between (a) ossa-ref and ctrl (range from -78 to $150 \%$ ) and (b) ossa-ref and ossa-salt (range from -66 to $102 \%$ ).

a)

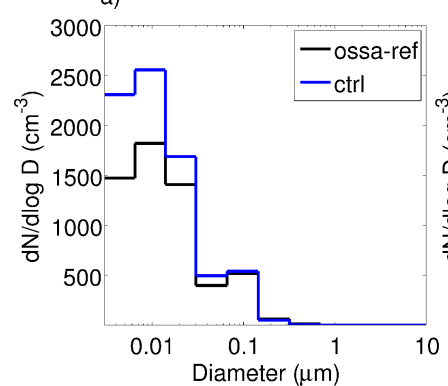

b)

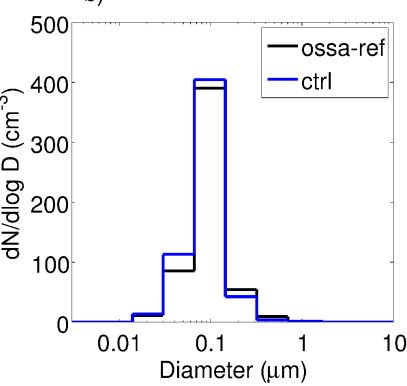

Figure 15. Five-year mean size distribution over the Southern Ocean in the five lowest model levels (about up to $1 \mathrm{~km}$ ) (a) of all aerosol particles, and (b) of particles activated to cloud droplets. The size-resolved number of activated cloud droplets was diagnosed also for cloud-free time steps and may thus differ from the distribution diagnosed for only cloudy time steps. The diameter refers to dry size in both panels.

capsulates wave state (Ovadnevaite et al., 2014) with the organic fraction parameterized following Rinaldi et al. (2013), against both in situ and satellite measurements. We used the model to predict the direct and indirect radiative effect of sea spray aerosol particles consisting of both sea salt and primary marine organic matter (PMOM).

The model with the new parameterization predicted global annual mean emissions of sea salt to be $805 \mathrm{Tg} \mathrm{yr}^{-1}$ (with a sensitivity range of $378-1233 \mathrm{Tg} \mathrm{yr}^{-1}$ ) and emissions of PMOM to be $1.1 \mathrm{Tg} \mathrm{yr}^{-1}$ (with a sensitivity range of $0.5-1.8 \mathrm{Tg} \mathrm{yr}^{-1}$ ), both of which are considerably lower than the typical range given in previous studies. However, our simulations agreed reasonably well with long-term in situ measurements at three marine or coastal sites, showing a low bias of $-13 \%$ at Mace Head and $-29 \%$ at Point Reyes for $\mathrm{PM}_{2.5}$ sea salt concentration, and a high bias of $899 \%$ for $\mathrm{PM}_{2.5-10}$ sodium ion concentration at Amsterdam Island. This suggests that at least the upper range of previous estimates of global sea spray aerosol emissions is likely to be unrealistic. The model underpredicted PMOM, especially during the summer months. This was probably due to both the low magnitude of the total sea spray aerosol flux and the fact that the Rinaldi et al. (2013) parameterization takes into ac-

count mixing of organic-rich and organic-poor layers of the ocean at high wind speeds, and thus predicts a lower mass fraction of PMOM in sea spray aerosol particles compared to previous studies.

Overall, the model with the extended OSSA source function underestimated AOD compared to the values retrieved using satellite data (PARASOL). However, agreement between measured and modelled values clearly improved in the Tropics and mid-latitudes compared to the default sea spray aerosol source function. The annual mean AOD retrieved from the PARASOL satellite was within the uncertainty limits of the new sea spray aerosol source function (evaluated by two sensitivity simulations with high and low estimates of the source function) across $36 \%$ of the oceans. The contributions from other major aerosol sources such as dust and anthropogenic emissions were likely causing part of the disagreement between the AOD estimate from PARASOL and ECHAM-HAMMOZ in some oceanic regions. In the region between the equator and $45^{\circ} \mathrm{S}$, which contains some of the more pristine oceanic regions, the annual mean AOD from PARASOL was within the sensitivity range in $60 \%$ of the area. When looking at individual monthly means, the PARASOL-retrieved AOD fell outside the modelled uncertainty range most often in model grid cells with low Reynolds number (i.e. low wind speed or small significant wave height). This indicates that some fine-tuning may be needed for the threshold Reynolds numbers for different modes of the new sea spray aerosol source function. When compared against AOD from sun photometer measurements at several island and coastal stations of the AERONET network, the modelled monthly mean AOD performed well with correlation coefficients ranging from 0.66 to 0.83 in different seasons.

In contrast to several previous studies (e.g. Ayash et al., 2008; Ma et al., 2008), the model predicted that sea spray aerosol emissions had a positive indirect effect (global mean of $0.30 \mathrm{~W} \mathrm{~m}^{-2}$ ). Although primary CCN emissions increased, the additional surface area provided by the large sea salt particles prevented both sulfuric acid and water from condensing onto smaller particles, and thus decreased the total number of CCN and the CDNC. Our results agreed well with other global simulations where competition effects were 
taken into account (Gong and Barrie, 2003; Korhonen et al., 2010). Despite the positive indirect effect, the total radiative effect of sea spray aerosol emissions was negative due to a negative direct effect (global mean of $-0.50 \mathrm{~W} \mathrm{~m}^{-2}$ ) more than compensating for the positive indirect effect.

The simulated organic fraction in sea spray aerosol was small $\left(0.1 \%\right.$ in $\mathrm{PM}_{10}$, and $4 \%$ in particles smaller than $700 \mathrm{~nm}$ in dry diameter), which was reflected in the minor radiative effects PMOM. Averaged over the year, the PMOM had a small cooling indirect effect (global mean of $-0.07 \mathrm{~W} \mathrm{~m}^{-2}$ ) most likely due to the low water uptake of PMOM in subsaturated conditions that decreased the condensation sink of sulfate and thus increased the number of small particles. On the other hand, the low water uptake of PMOM led to a positive direct effect of PMOM (global mean of $0.03 \mathrm{~W} \mathrm{~m}^{-2}$ ).

Overall, our study shows that even if total global emissions of PMOM are lower than several previous studies predict, they can still have effects on the global radiative budget. However, there are still large uncertainties in estimating the physical, chemical and optical properties of PMOM, and the uncertainty is naturally even larger when modelling its climate effects on a global scale.

\section{The Supplement related to this article is available online at doi:10.5194/acp-14-11731-2014-supplement.}

Acknowledgements. This work was supported by the European Space Agency (Support To Science Element: Oceanflux Sea Spray Aerosol, contract no. 4000104514/11/I-AM) and the Academy of Finland (Academy Research Fellow position (250348) and research project (256208)). Mikko Aalto is thanked for providing the wave height data from ECMWF data base. ECMWF ERA-Interim data used in this study have been obtained from the ECMWF Data Server. Thanks to Shubha Sathyendrath for helpful discussion on satellite retrievals of chlorophyll, and Salvatore Marullo for advice on gap-filling methods in satellite data. Chlorophyll data were obtained from the GlobColour website (http://www.globcolour.info/). GlobColour has been initiated and funded by the ESA Data User Element Programme. The AOD data from PARASOL were obtained from ICARE Data and Services Center (http://www.icare.univ-lille1.fr). ESA Climate Change Initiative and Aerosol-cci project are ackowledged for providing the PARASOL data. We thank the AERONET and EMEP Principal Investigators and their staff for establishing and maintaining the sites used in this investigation. Measurements from Point Reyes are part of the IMPROVE network, and the authors thank Nicholas Meskhidze and his group for providing the data. Results obtained at Amsterdam Island were supported by the French Polar Institute (IPEV) within the AEROTRACE project, and measurements at Mace Head were supported by ACTRIS, EPA, and HEA-PRTLI4. The ECHAM-HAMMOZ model is developed by a consortium composed of ETH Zurich, Max Planck Institut für Meteorologie, Forschungszentrum Jülich, University of Oxford, and the Finnish Meteorological Institute and managed by the Center for Climate Systems Modeling (C2SM) at ETH Zurich.

Edited by: K. Tsigaridis

\section{References}

Aas, E.: Refractive index of phytoplankton derived from its metabolite composition, J. Plankton Res., 18, 2223-2249, 1996.

Abdul-Razzak, H. and Ghan, S. J.: A parameterization of aerosol activation: 3. sectional representation, J. Geophys. Res., 107, D34026, doi:10.1029/2001JD000483, 2002.

Abdul-Razzak, H., Ghan, S. J., and Rivera-Carpio, C.: A parameterization of aerosol activation, Part I: Single aerosol type, J. Geophys. Res., 103, 6123-6131, 1998.

Albert, M. F. M. A., Schaap, M., Scannell, C., O’Dowd, C. D., and de Leeuw, G.: Uncertainties in the determination of the organic fraction of global sub-micron sea-spray emissions, Atmos. Environ., 57, 289-300, doi:10.1016/j.atmosenv.2012.04.009, 2012.

Allan, J. D., Jimenez, J. L., Williams, P. I., Alfarra, M. R., Bower, K. N., Jayne, J. T., Coe, H., and Worsnop, D. R.: Quantitative sampling using an Aerodyne aerosol mass spectrometer 1. Techniques of data interpretation and error analysis, J. Geophys. Res.-Atmos., 108, D34090, doi:10.1029/2002jd002358, 2003.

Andersson, C., Bergström, R., Bennet, C., Robertson, L., Thomas, M., Korhonen, H., Lehtinen, K. E. J., and Kokkola, H.: MATCHSALSA - Multi-scale Atmospheric Transport and CHemistry model coupled to the SALSA aerosol microphysics model - Part 1: Model description and evaluation, Geosci. Model Dev. Discuss., 7, 3265-3305, doi:10.5194/gmdd-7-3265-2014, 2014.

Andreas, E. L.: A New Sea Spray Generation Function for Wind Speeds up to $32 \mathrm{~ms}^{-1}$, J. Phys. Oceanogr., 28, 2175-2184, doi:10.1175/1520-0485(1998)028<2175:ANSSGF>2.0.CO;2, 1998.

Ayash, T., Gong, S. L., and Jia, C.: Direct and indirect shortwave radiative effects of sea salt aerosols, J. Climate, 21, 3207-3220, doi:10.1175/2007JCLI2063.1, 2008.

Bates, T. S., Quinn, P. K., Frossard, A. A., Russell, L. M., Hakala J., Petäjä, T., Kulmala, M., Covert, D. S., Cappa, C. D., Li, S.-M., Hayden, K. L., Nuaaman, I., McLaren, R., Massoli, P., Canagaratna, M. R, Onasch, T. B., Sueper, D., Worsnop, D. R., and Keene, W. C.: Measurements of ocean derived aerosol off the coast of California, J. Geophys. Res., 117, D00V15, doi:10.1029/2012JD017588, 2012.

Bergman, T., Kerminen, V.-M., Korhonen, H., Lehtinen, K. J., Makkonen, R., Arola, A., Mielonen, T., Romakkaniemi, S., Kulmala, M., and Kokkola, H.: Evaluation of the sectional aerosol microphysics module SALSA implementation in ECHAM5HAM aerosol-climate model, Geosci. Model Dev., 5, 845-868, doi:10.5194/gmd-5-845-2012, 2012.

Bréon, F.-M., Vermeulen, A., and Descloitres, J.: An evaluation of satellite aerosol products against sunphotometer measurements, Remote Sens. Environ., 115, 3102-3111, doi:10.1016/j.rse.2011.06.017, 2011.

Carslaw, K. S., Lee, L. A., Reddington, C. L., Pringle, K. J., Rap, A., Forster, P. M., Mann, G. W., Spracklen, D. V., Woodhouse, M. T., Regayre, L. A., and Pierce, J. R.: Large contribution of natural 
aerosols to uncertainty in indirect forcing, Nature, 503, 67-71, 2013.

Croft, B., Lohmann, U., Martin, R. V., Stier, P., Wurzler, S., Feichter, J., Hoose, C., Heikkilä, U., van Donkelaar, A., and Ferrachat, S.: Influences of in-cloud aerosol scavenging parameterizations on aerosol concentrations and wet deposition in ECHAM5-HAM, Atmos. Chem. Phys., 10, 1511-1543, doi:10.5194/acp-10-1511-2010, 2010.

DeCarlo, P. F., Kimmel, J. R., Trimborn, A., Northway, M. J., Jayne, J. T., Aiken, A. C., Gonin, M., Fuhrer, K., Horvath, T., Docherty, K. S., Worsnop, D. R., and Jimenez, J. L.: Fielddeployable, high-resolution, time-of-flight aerosol mass, Anal. Chem., 78, 8281-8289, 2006.

Dee, D. P., Uppala, S. M., Simmons, A. J., Berrisford, P., Poli, P., Kobayashi, S., Andrae, U., Balmaseda, M. A., Balsamo, G., Bauer, P., Bechtold, P., Beljaars, A. C. M., van de Berg, L., Bidlot, J., Bormann, N., Delsol, C., Dragani, R., Fuentes, M., Geer, A. J., Haimberger, L., Healy, S. B., Hersbach, H., Hólm, E. V., Isaksen, L., Kållberg, P., Köhler, M., Matricardi, M., McNally, A. P., Monge-Sanz, B. M., Morcrette, J.-J., Park, B.K., Peubey, C., de Rosnay, P., Tavolato, C., Thépaut, J.-N., and Vitart, F.: The ERA-Interim reanalysis: configuration and performance of the data assimilation system, Q. J. Roy. Meteor. Soc., 137, 553-597, doi:10.1002/qj.828, 2011.

de Leeuw, G., Andreas, E. L., Anguelova, M. D., Fairall, C. W., Lewis, E. R., O'Dowd, C., Schulz, M., and Schwartz, S. E.: Production flux of sea spray aerosol, Rev. Geophys., 49, RG2001, doi:10.1029/2010RG000349, 2011.

de Leeuw, G., Holzer-Popp, T., Bevan, S., Davies, W., Descloitres, J., Grainger, R. G., Griesfeller, J., Heckel, A., Kinne, S., Klüser, L., Kolmonen, P., Litvinov, P., Martynenko, D., North, P. J. R., Ovigneur, B., Pascal, N., Poulsen, C., Ramon, D., Schulz, M., Siddans, R., Sogacheva, L., Tanré, D., Thomas, G. E., Virtanen, T. H., von Hoyningen Huene, W., Vountas, M., and Pinnock, S.: Evaluation of seven European aerosol optical depth retrieval algorithms for climate analysis, Remote Sens. Environ., in press, doi:10.1016/j.rse.2013.04.023, 2013.

Deschamps, P. Y., Breon, F. M., Leroy, M., Podaire, A., Seze, G., and Bricaud, A.: The POLDER mission: instrument characteristics and scientific objectives, IEEE T. Geosci. Remote, 32, 598-615, 1994.

Eck, T. F., Holben, B. N., Reid, J. S., Dubovik, O., Smirnov, A., O'Neill, N. T., Slutsker, I., and Kinne, S.: Wavelength dependence of the optical depth of biomass burning, urban, and desert dust aerosols, J. Geophys. Res., 104, 31333-31349, doi:10.1029/1999JD900923, 1999.

Facchini, M. C., Rinaldi, M., Decesari, S., Carbone, C., Finessi, E., Mircea, M., Fuzzi, S., Ceburnis, D., Flanagan, R., Nilsson, E. D., de Leeuw, G., Martino, M., Woeltjen, J., and O'Dowd, C. D.: Primary submicron marine aerosol dominated by insoluble organic colloids and aggregates, Geophys. Res. Lett., 35, L17814, doi:10.1029/2008GL034210, 2008.

Forster, P., Ramaswamy, V., Artaxo, P., Berntsen, T., Betts, R., Fahey, D. W., Haywood, J., Lean, J., Lowe, D. C., Myhre, G., Nganga, J., Prinn, R., Raga, G., Schulz, M., and Van Dorland, R.: Radiative Forcing of Climate Change, in Climate Change 2007: The Physical Science Basis, Contribution of Working Group I to the Fourth Assessment Report of the Intergovernmental Panel on Climate Change, edited by: Solomon, S., Qin, D., Man- ning, M., Chen, Z., Marquis, M., Averyt, K. B., Tignor, M., and Miller, H. L., Cambridge Univ. Press, Cambridge, UK and New York, NY, USA, 129-234, 2007.

Fuentes, E., Coe, H., Green, D., de Leeuw, G., and McFiggans, G.: Laboratory-generated primary marine aerosol via bubblebursting and atomization, Atmos. Meas. Tech., 3, 141-162, doi:10.5194/amt-3-141-2010, 2010a.

Fuentes, E., Coe, H., Green, D., de Leeuw, G., and McFiggans, G.: On the impacts of phytoplankton-derived organic matter on the properties of the primary marine aerosol - Part 1: Source fluxes, Atmos. Chem. Phys., 10, 9295-9317, doi:10.5194/acp-10-92952010, 2010b.

Gantt, B. and Meskhidze, N.: The physical and chemical characteristics of marine primary organic aerosol: a review, Atmos. Chem. Phys., 13, 3979-3996, doi:10.5194/acp-13-3979-2013, 2013.

Gantt, B., Meskhidze, N., Facchini, M. C., Rinaldi, M., Ceburnis, D., and O'Dowd, C. D.: Wind speed dependent size-resolved parameterization for the organic mass fraction of sea spray aerosol, Atmos. Chem. Phys., 11, 8777-8790, doi:10.5194/acp-11-87772011, 2011.

Gantt, B., Johnson, M. S., Meskhidze, N., Sciare, J., Ovadnevaite, J., Ceburnis, D., and O'Dowd, C. D.: Model evaluation of marine primary organic aerosol emission schemes, Atmos. Chem. Phys., 12, 8553-8566, doi:10.5194/acp-12-8553-2012, 2012.

Ghan, S. J., Guzman, G., and Abdul-Razzak, H.: Competition between sea salt and sulfate particles as cloud condensation nuclei, J. Atmos. Sci., 55, 3340-3347, 1998.

Gong, S. L.: A parameterization of sea-salt aerosol source function for sub- and supermicron particles, Global Biogeochem. Cy., 17, 1097, doi:10.1029/2003GB002079, 2003.

Gong, S. L. and Barrie, L. A.: Simulating the impact of sea salt on global nss sulphate aerosols, J. Geophys. Res., 108, D164516, doi:10.1029/2002JD003181, 2003.

Grythe, H., Ström, J., Krejci, R., Quinn, P., and Stohl, A.: A review of sea-spray aerosol source functions using a large global set of sea salt aerosol concentration measurements, Atmos. Chem. Phys., 14, 1277-1297, doi:10.5194/acp-14-1277-2014, 2014.

Guelle, W., Schulz, M., Balkanski, Y., and Dentener, F.: Influence of the source formulation on modeling the atmospheric global distribution of sea salt aerosol, J. Geophys. Res., 106, 27509-27524, doi:10.1029/2001JD900249, 2001.

Hawkins, L. N. and Russell, L. M.: Polysaccharides, proteins, and phytoplankton fragments: four chemically distinct types of marine primary organic aerosol classified by single particle spectromicroscopy, Adv. Meteorol., 2010, 612132, doi:10.1155/2010/612132, 2010.

Haywood, J. M., Ramaswamy, V., and Soden, B. J.: Tropospheric aerosol climate forcing in clear-sky satellite observations over the oceans, Science, 283, 1299-1303, doi:10.1126/science.283.5406.1299, 1999.

Haywood, J., Donner, L., Jones, A., and Golaz, J.-C.: Global indirect radiative forcing caused by aerosols: IPCC (2007) and beyond, in: Clouds in the Perturbed Climate System: Their Relationship to Energy Balance, Atmospheric Dynamics, and Precipitation: Strüngmann Forum Report, edited by: Heintzenberg, J. and Charlson, R. J., MIT Press, Cambridge, Mass., 451-467, 2009.

Henning, S., Bojinski, S., Diehl, K., Ghan, S., Nyeki, S., Weingartner, E., Wurzler, S., and Baltensperger, U.: Aerosol partitioning 
in natural mixed-phase clouds, Geophys. Res. Lett., 31, L06101, doi:10.1029/2003GL019025, 2004.

Holben, B. N., Eck, T. F., Slutsker, I., Tanre, D., Buis, J. P., Setzer, A., Vermote, E., Reagan, J. A., Kaufman, Y. J., Nakajima, T., Lavenu, F., Jankowiak, I., and Smirnov, A.: AERONET - a federated instrument network and data archive for aerosol characterization, Remote Sens. Environ., 66, 1-16, 1998.

Hultin, K. A. H., Nilsson, E. D., Krejci, R., Mårtensson, E. M., Ehn, M., Hagström, A., and de Leeuw, G.: In situ laboratory sea spray production during the Marine Aerosol Production 2006 cruise on the northeastern Atlantic Ocean, J. Geophys. Res., 115, D06201, doi:10.1029/2009JD012522, 2010.

Jaeglé, L., Quinn, P. K., Bates, T. S., Alexander, B., and Lin, J.-T.: Global distribution of sea salt aerosols: new constraints from in situ and remote sensing observations, Atmos. Chem. Phys., 11, 3137-3157, doi:10.5194/acp-11-3137-2011, 2011.

Jimenez, J. L., Jayne, J. T., Shi, Q., Kolb, C. E., Worsnop, D. R., Yourshaw, I., Seinfeld, J. H., Flagan, R. C., Zhang, X., Smith, K. A., Morris, J. W., and Davidovits, P.: Ambient aerosol sampling using the Aerodyne Aerosol Mass Spectrometer, J. Geophys. Res., 108, D78425, doi:10.1029/2001JD001213, 2003.

Kanakidou, M., Seinfeld, J. H., Pandis, S. N., Barnes, I., Dentener, F. J., Facchini, M. C., Van Dingenen, R., Ervens, B., Nenes, A., Nielsen, C. J., Swietlicki, E., Putaud, J. P., Balkanski, Y., Fuzzi, S., Horth, J., Moortgat, G. K., Winterhalter, R., Myhre, C. E. L., Tsigaridis, K., Vignati, E., Stephanou, E. G., and Wilson, J.: Organic aerosol and global climate modelling: a review, Atmos. Chem. Phys., 5, 1053-1123, doi:10.5194/acp-5-1053-2005, 2005.

King, S. M., Butcher, A. C., Rosenoern, T., Coz, E., Lieke, K. I., de Leeuw, G., Nilsson, E. D., Bilde, M.: Investigating primary marine aerosol properties: $\mathrm{CCN}$ activity of sea salt and mixed inorganic-organic particles, Environ. Sci. Technol., 46, 10405-10412, doi:10.1021/es300574u, 2012.

Kokkola, H., Korhonen, H., Lehtinen, K. E. J., Makkonen, R., Asmi, A., Järvenoja, S., Anttila, T., Partanen, A.-I., Kulmala, M., Järvinen, H., Laaksonen, A., and Kerminen, V.-M.: SALSA - a Sectional Aerosol module for Large Scale Applications, Atmos. Chem. Phys., 8, 2469-2483, doi:10.5194/acp-8-2469-2008, 2008.

Kondrashov, D. and Ghil, M.: Spatio-temporal filling of missing points in geophysical data sets, Nonlin. Processes Geophys., 13, 151-159, doi:10.5194/npg-13-151-2006, 2006.

Korhonen, H., Carslaw, K. S., Spracklen, D. V., Mann, G. W., and Woodhouse, M. T.: Influence of oceanic dimethyl sulfide emissions on cloud condensation nuclei concentrations and seasonality over the remote Southern Hemisphere oceans: a global model study, J. Geophys. Res., 113, D15204, doi:10.1029/2007JD009718, 2008.

Korhonen, H., Carslaw, K. S., and Romakkaniemi, S.: Enhancement of marine cloud albedo via controlled sea spray injections: a global model study of the influence of emission rates, microphysics and transport, Atmos. Chem. Phys., 10, 4133-4143, doi:10.5194/acp-10-4133-2010, 2010.

Kulmala, M., Lehtinen, K. E. J., and Laaksonen, A.: Cluster activation theory as an explanation of the linear dependence between formation rate of $3 \mathrm{~nm}$ particles and sulphuric acid concentration, Atmos. Chem. Phys., 6, 787-793, doi:10.5194/acp-6-787-2006, 2006.
L'Ecuyer, T. S. and Jiang, J. H.: Touring the atmosphere aboard the A-Train, Phys. Today, 63, 36-41, doi:10.1063/1.3463626, 2010.

Leck, C. and Bigg, E. K.: Source and evolution of the marine aerosol - a new perspective, Geophys. Res. Lett., 32, L19803, doi:10.1029/2005GL023651, 2005.

Li, J., Ma, X., von Salzen, K., and Dobbie, S.: Parameterization of sea-salt optical properties and physics of the associated radiative forcing, Atmos. Chem. Phys., 8, 4787-4798, doi:10.5194/acp-84787-2008, 2008.

Lohmann, U. and Hoose, C.: Sensitivity studies of different aerosol indirect effects in mixed-phase clouds, Atmos. Chem. Phys., 9, 8917-8934, doi:10.5194/acp-9-8917-2009, 2009.

Long, M. S., Keene, W. C., Kieber, D. J., Frossard, A. A., Russell, L. M., Maben, J. R., Kinsey, J. D., Quinn, P. K., and Bates T. S.: Light-enhanced primary marine aerosol production from biologically productive seawater, Geophys. Res. Lett., 41, 2661-2670, doi:10.1002/2014GL059436, 2014.

Ma, X., von Salzen, K., and Li, J.: Modelling sea salt aerosol and its direct and indirect effects on climate, Atmos. Chem. Phys., 8, 1311-1327, doi:10.5194/acp-8-1311-2008, 2008.

Malm, W. C., Schichtel, B. A., Pitchford, M. L., Ashbaugh, L. L., and Eldred, R. A.: Spatial and monthly trends in speciated fine particle concentration in the United States, J. Geophys. Res.Atmos., 109, D03306, doi:10.1029/2003JD003739, 2004.

Maritorena, S. and Siegel. D. A.: Consistent merging of satellite ocean color data sets using a bio-optical model, Remote Sens. Environ., 94, 429-440, doi:10.1016/j.rse.2004.08.014, 2005.

Meskhidze, N., Xu, J., Gantt, B., Zhang, Y., Nenes, A., Ghan, S. J., Liu, X., Easter, R., and Zaveri, R.: Global distribution and climate forcing of marine organic aerosol: 1 . Model improvements and evaluation, Atmos. Chem. Phys., 11, 11689-11705, doi:10.5194/acp-11-11689-2011, 2011.

Middlebrook, A. M., Murphy, D. M., and Thomson, D. S.: Observations of organic material in individual marine particles at Cape Grim during the First Aerosol Characterization Experiment (ACE1), J. Geophys. Res., 103, 16475-16483, doi:10.1029/97JD03719, 1998.

Mielonen, T., Levy, R. C., Aaltonen, V., Komppula, M., de Leeuw, G., Huttunen, J., Lihavainen, H., Kolmonen, P., Lehtinen, K. E. J., and Arola, A.: Evaluating the assumptions of surface reflectance and aerosol type selection within the MODIS aerosol retrieval over land: the problem of dust type selection, Atmos. Meas. Tech., 4, 201-214, doi:10.5194/amt-4-201-2011, 2011.

Monahan, E. C., Spiel, D. E., and Davidson, K. L.: A model of marine aerosol generation via whitecaps and wave disruption, in: Oceanic Whitecaps and their Role in Air-Sea Exchange, edited by: Monahan, E. C. and MacNiocaill, G., D. Reidel, Norwell, Mass., 167-174, 1986.

Nessler, R., Weingartner, E., and Baltensperger, U.: Adaptation of dry nephelometer measurements to ambient conditions at the Jungfraujoch, Environ. Sci. Technol., 39, 2219-2228, doi:10.1021/es035450g, 2005.

Norris, S. J., Brooks, I. M., Hill, M. K., Brooks, B. J., Smith, M. H., and Sproson, D. A. J.: Eddy covariance measurements of the sea spray aerosol flux over the open ocean, J. Geophys. Res., 117, D07210, doi:10.1029/2011jd016549, 2012.

Novakov, T., Corrigan, C. E., Penner, J. E., Chuang, C. C., Rosario, O., and Mayel Bracero, O. L.: Organic aerosols in the 
Caribbean trade winds: a natural source?, J. Geophys. Res., 102, 21307-23313, doi:10.1029/97JD01487, 1997.

O'Connor, T. C., Jennings, S. G, and O'Dowd, C. D.: Highlights of fifty years of atmospheric aerosol research at Mace Head, Atmos. Res., 90, 338-355, 2008.

O'Dowd, C., Lowe, J. A., and Smith, M. H.: Coupling sea-salt and sulphate interactions and its impact on cloud droplet concentration predictions, Geophys. Res. Lett., 26, 1311-1314, 1999a.

O'Dowd, C., Lowe, J. A., Smith, M. H, and Kaye, A. D.: The relative importance of non-sea-salt sulphate and sea-salt aerosol to the marine cloud condensation nuclei population: an improved multi-component aerosol-cloud droplet parameterization, Q. J. Roy. Meteor. Soc., 125, 1295-1313, 1999b.

O’Dowd, C. D., Hämeri, K., Mäkelä, J. M., Pirjola, L., Kulmala, M., Jennings, S. G., Berresheim, H., Hansson, H. C., de Leeuw, G., Kunz, G. J., Allen, A. G., Hewitt, C. N., Jackson, A., Viisanen, Y., and Hoffmann, T.: A dedicated study of new particle formation and fate in the coastal environment (PARFORCE): overview of objectives and achievements, J. Geophys. Res., 197, 8108, doi:10.1029/2001JD000555, 2002

O'Dowd, C. D., Facchini, M. C., Cavalli, F., Ceburnis, D., Mircea, M., Decesari, S., Fuzzi, S., Yoon, Y. J., and Putaud, J. P.: Biogenically driven organic contribution to marine aerosol, Nature, 431, 676-680, doi:10.1038/nature02959, 2004.

Ovadnevaite, J., Ceburnis, D., Martucci, G., Bialek, J., Monahan, C., Rinaldi, M., Facchini, M. C., Berresheim, H., Worsnop, D. R., and O'Dowd, C.: Primary marine organic aerosol: a dichotomy of low hygroscopicity and high CCN activity, Geophys. Res. Lett., 38, L21806, doi:10.1029/2011GL048869, 2011.

Ovadnevaite, J., Ceburnis, D., Canagaratna, M., Berresheim, H., Bialek, J., Martucci, G., Worsnop, D. R., and O'Dowd, C.: On the effect of wind speed on submicron sea salt mass concentrations and source fluxes, J. Geophys. Res.-Atmos., 117, doi:10.1029/2011jd017379, 2012.

Ovadnevaite, J., Manders, A., de Leeuw, G., Ceburnis, D., Monahan, C., Partanen, A.-I., Korhonen, H., and O'Dowd, C. D.: A sea spray aerosol flux parameterization encapsulating wave state, Atmos. Chem. Phys., 14, 1837-1852, doi:10.5194/acp-14-18372014, 2014.

Petters, M. D. and Kreidenweis, S. M.: A single parameter representation of hygroscopic growth and cloud condensation nucleus activity, Atmos. Chem. Phys., 7, 1961-1971, doi:10.5194/acp-71961-2007, 2007.

Pierce, J. R. and Adams, P. J.: Global evaluation of CCN formation by direct emission of sea salt and growth of ultrafine sea salt, J. Geophys. Res., 111, D06203, doi:10.1029/2005JD006186, 2006.

Pringle, K. J., Tost, H., Pozzer, A., Pöschl, U., and Lelieveld, J.: Global distribution of the effective aerosol hygroscopicity parameter for CCN activation, Atmos. Chem. Phys., 10, 5241-5255, doi:10.5194/acp-10-5241-2010, 2010.

Quinn, P. K., Bates, T. S., Schulz, K. S., Coffman, D. J., Frossard, A. A., Russel, L. M., Keene, W. C., and Kieber, D. J.: Contribution of sea surface carbon pool to organic matter enrichment in sea spray aerosol, Nature Geo. Sci., 7, 228-232, doi:10.1038/ngeo2092, 2014.

Rap, A., Scott, C. E., Spracklen, D. V., Bellouin, N., Forster, P. M., Carslaw, K. S., Schmidt, A., and Mann, G.: Natural aerosol direct and indirect radiative effects, Geophys. Res. Lett., 40, 3297-3301, doi:10.1002/grl.50441, 2013.

Reddy, M. S., Boucher, O., Balkanski, Y., and Schulz, M. Aerosol optical depths and direct radiative perturbations by species and source type, Geophys. Res. Lett., 32, L12803, doi:10.1029/2004GL021743, 2005.

Riahi, K., Gruebler, A., and Nakicenovic, N.: Scenarios of longterm socio-economic and environmental development under climate stabilization, Technol. Forecast. Soc., 74, 887-935, doi:10.1016/j.techfore.2006.05.026, 2007.

Riahi, K., Rao, S., Krey, V., Cho, C., Chirkov, V., Fischer, G., Kindermann, G., Nakicenovic, N., and Rafaj, P.: RCP 8.5 - a scenario of comparatively high greenhouse gas emissions, Climatic Change, 109, 33-57, doi:10.1007/s10584-011-0149-y, 2011.

Rinaldi, M., Fuzzi, S., Decesari, S., Marullo, S., Santoleri, R., Provenzale, A., von Hardenberg, J., Ceburnis, D., Vaishya, A., O'Dowd, C. D., and Facchini, M. C.: Is chlorophyll $a$ the best surrogate for organic matter enrichment in submicron primary marine aerosol?, J. Geophys. Res.-Atmos., 118, 4964-4973, doi:10.1002/jgrd.50417, 2013

Schmitt-Kopplin, P., Liger-Belair, G., Koch, B. P., Flerus, R., Kattner, G., Harir, M., Kanawati, B., Lucio, M., Tziotis, D., Hertkorn, N., and Gebefügi, I.: Dissolved organic matter in sea spray: a transfer study from marine surface water to aerosols, Biogeosciences, 9, 1571-1582, doi:10.5194/bg-9-1571-2012, 2012.

Sciare, J., Favez, O., Sarda-Estève, R., Oikonomou, K., Cachier, H., and Kazan, V.: Long-term observations of carbonaceous aerosols in the Austral Ocean atmosphere: evidence of a biogenic marine organic source, J. Geophys. Res., 114, D15302, doi:10.1029/2009JD011998, 2009.

Sharqawy, M. H., Lienhard, J. H., and Zubair, S. M.: Thermophysical properties of seawater: a review of existing correlations and data, Desalination and Water Treatment, 16, 354-380, doi:10.5004/dwt.2010.1079, 2010.

Stier, P., Feichter, J., Kinne, S., Kloster, S., Vignati, E., Wilson, J., Ganzeveld, L., Tegen, I., Werner, M., Balkanski, Y., Schulz, M., Boucher, O., Minikin, A., and Petzold, A.: The aerosol-climate model ECHAM5-HAM, Atmos. Chem. Phys., 5, 1125-1156, doi:10.5194/acp-5-1125-2005, 2005.

Stokes, R. H. and Robinson, R. A.: Interactions in aqueous nonelectrolyte solutions. I. Solute-solvent equilibria, J. Phys. Chem., 70, 2126-2130, 1996.

Tanré, D., Bréon, F. M., Deuzé, J. L., Dubovik, O., Ducos, F., François, P., Goloub, P., Herman, M., Lifermann, A., and Waquet, F.: Remote sensing of aerosols by using polarized, directional and spectral measurements within the A-Train: the PARASOL mission, Atmos. Meas. Tech., 4, 1383-1395, doi:10.5194/amt-4-1383-2011, 2011

Textor, C., Schulz, M., Guibert, S., Kinne, S., Balkanski, Y., Bauer, S., Berntsen, T., Berglen, T., Boucher, O., Chin, M., Dentener, F., Diehl, T., Easter, R., Feichter, H., Fillmore, D., Ghan, S., Ginoux, P., Gong, S., Grini, A., Hendricks, J., Horowitz, L., Huang, P., Isaksen, I., Iversen, I., Kloster, S., Koch, D., Kirkevåg, A., Kristjansson, J. E., Krol, M., Lauer, A., Lamarque, J. F., Liu, X., Montanaro, V., Myhre, G., Penner, J., Pitari, G., Reddy, S., Seland, $\varnothing .$, Stier, P., Takemura, T., and Tie, X.: Analysis and quantification of the diversities of aerosol life cycles within AeroCom, At- 
mos. Chem. Phys., 6, 1777-1813, doi:10.5194/acp-6-1777-2006, 2006.

Tsigaridis, K., Koch, D., and Menon, S.: Uncertainties and importance of sea spray composition on aerosol direct and indirect effects, J. Geophys. Res., 118, 220-235, doi:10.1029/2012JD018165, 2013.

Uppala, S. M., Kallberg, P. W., Simmons, A. J., Andrae, U., Bechtold, V. D., Fiorino, M., Gibson, J. K., Haseler, J., Hernandez, A., Kelly, G. A., Li, X., Onogi, K., Saarinen, S., Sokka, N., Allan, R. P., Andersson, E., Arpe, K., Balmaseda, M. A., Beljaars, A. C. M., Van De Berg, L., Bidlot, J., Bormann, N., Caires, S., Chevallier, F., Dethof, A., Dragosavac, M., Fisher, M., Fuentes, M., Hagemann, S., Holm, E., Hoskins, B. J., Isaksen, L., Janssen, P., Jenne, R., McNally, A. P., Mahfouf, J. F., Morcrette, J. J., Rayner, N. A., Saunders, R. W., Simon, P., Sterl, A., Trenberth, K. E., Untch, A., Vasiljevic, D., Viterbo, P., and Woollen, J.: The ERA-40 re-analysis, Q. J. Roy. Meteor. Soc., 131, 2961-3012, doi:10.1256/qj.04.176, 2005.
Vaishya, A., Ovadnevaite, J., Bialek, J., Jennings, S. G., Ceburnis, D., and O'Dowd, C. D.: Bistable effect of organic enrichment on sea spray radiative properties, Geophys. Res. Lett., 40, 6395-6398, doi:10.1002/2013GL058452, 2013.

Vignati, E., Facchini, M. C., Rinaldi, M., Scannell, C., Ceburnis, D., Sciare, J., Kanakidou, M., Myriokefalitakis, S., Dentener, F., and O'Dowd, C. D.: Global scale emission and distribution of seaspray aerosol: sea-salt and organic enrichment, Atmos. Environ., 44, 670-677, 2010.

Zhang, K., O'Donnell, D., Kazil, J., Stier, P., Kinne, S., Lohmann, U., Ferrachat, S., Croft, B., Quaas, J., Wan, H., Rast, S., and Feichter, J.: The global aerosol-climate model ECHAM-HAM, version 2: sensitivity to improvements in process representations, Atmos. Chem. Phys., 12, 8911-8949, doi:10.5194/acp-12-89112012, 2012. 